\title{
Manufacturing and Producer Services Integration in Empirical Analysis of the Yangtze River Economic Belt
}

\author{
Ling Yang ${ }^{a}$, Pengzhi Xu,
}

School of Economics, Shanghai University, China

add20130707@163.com

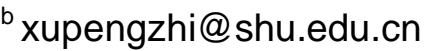

Keywords: integration, manufacturing and producer services, Yangtze River Economic Belt

\begin{abstract}
As the golden area, the Yangtze River Economic Belt is a strategic area for the upgrade of China's manufacturing industry. Although Jiangsu, Zhejiang, and Shanghai as the first ones to implement opening up policies of services and develop advanced manufacturing, the integration between manufacturing and producer services is still not complete, it is just the integration in width, but not in depth. This is not enough to promote manufacturing upgrade. In particular, there are advantages of breadth integration between manufacturing and producer services in Shanghai and Chongqing, but they lack deep integration for short of local characteristics.
\end{abstract}

\section{Introduction}

The Yangtze River is known as the "Golden Waterway", and its flowing area- 9 provinces, 2 cities- and coastal economic belts constitute a golden corridor for China's economic development. This area covers 2.057 million square kilometers, accounting for $21.27 \%$ of China's size. It is a huge economic belt spanning eastern, central and western regions. It is also a river basin economic belt with most population and largest industrial scale in the world. Its automobile production accounts for $40 \%$ of China's, household electrical appliances $60 \%$, micro-computers $80 \%$, steel $30 \%$, and building materials $40 \%$. So it is an important industrial region in China, and its manufacturing upgrade is key to China's industrial upgrade. The concept of the Yangtze River Economic Belt originated from 1984 to 1985. The China Productivity Economics Research Association proposed the "Industrial Belt of Yangtze River". Since 1990, especially in June 1992, the Central Committee proposed a strategic blueprint dedicated to developing "Yangtze River Delta and the regions along the Yangtze River". The Fifth Plenary Session of the Fourteenth Central Committee further pointed out that it is necessary to build the Yangtze River economic belt centered on Shanghai.

After entering the 21st century, various regions along the Yangtze River have proposed many development strategies based on the national strategic position of the Yangtze River Economic Belt, such as downstream "Yangtze River Delta", midstream "two circles and one belt", and upstream "Chengdu and Chongqing Economic Zone". The construction of the Yangtze River Economic Belt requires us to plan the gradient development from east to west, from coast to inland, from major rivers to land arterial lines and connect Yangtze River Delta, midstream cities and Chengdu-Chongqing Economic Zone. The integration of industries, flow of factors, and unification of the market will create a new driving power that involves more than one-fifth of the country size and about 600 million people. We will work together to build the Yangtze River Economic Belt to be a golden economic belt with more coordinated economic system, more unified market, and more scientific mechanism, and make it a spatial layout of "one-axis, two-wings and three-poles". Currently, the development of the Yangtze River Economic Belt is not ideal. To break through the practical problems of unfriendly environment, insufficient resources, tricky manufacturing upgrade, regional imbalance, and short of regional linkage, we need to focus on developing service economy.

At present, the value-added effect made by the integration between services and manufacturing is usually neglected, instead firms only pursue the high added value created by services per se. This means that they ignore the sustainable development of economy produced by the mutual integration 
between manufacturing and services, and by the benignant interaction between virtual and real economy.

After the US financial crisis in 2008, the fourth industrial revolution dominated by the developed economies such as the United States and Britain shows that post-industrialized countries which used to only depend on services to develop their economy have realized that only developing services can maintain rapid accumulation of wealth in the short term, but this is at the expense of undermining long-term growth power. Because if we study the nature of services carefully, it is can be found that the pure services only provide products which are not attached to any tangible materials, and its actual role in economic activities is only to help accelerate circulation, in particular, the circulation of capital market. But if the circulation lacks the most basic physical products, it will cause economy idling, which is manifested by the decline in real purchasing power of currency, and magnification of asset bubble. Specifically, there is an expansion of monetary output caused by expansionary monetary policies conducted by developed economies such as United States, Europe and Japan, and this led to their deficit. This shift from creditor countries to debtor countries will in turn result in a series of social problems such as large-scale unemployment, bankruptcy caused by the bursting of asset bubble and the displacement caused by economic problems.

Therefore, based on the existing developing pattern- manufacturing servitization, and focusing on relatively developed Yangtze River Economic Belt, this paper further proposes that we must accelerate the integration between manufacturing and producer services. (It is referred to the integration between manufacturing servitization and service manufacturization in this paper). This needs to integrate human capital-intensive production factors such as high value-added knowledge, experience, management and technology into manufacturing process. This will effectively improve the low value-added traditional production links by R\&D, design, marketing, and comprehensive technical services. so firms can provide high quality manufactured products, and meet consumers' more demanding requirements for their improved living standards. In addition, it is also beneficial to accelerate the pace of China's supply-side structural reforms.

Therefore, we should learn from the lessons of developed economies such as United States, Japan and Britain that they were dedicated to developing service industry at first, after serious industrial hollowing out, then they turned to manufacturing. So in order to realize China's Manufacturing 2025, China should focus on not only manufacturing servisization but also service manufacturization. The service industry should be rooted in manufacturing industry, so that they can better realize the combination of real economy and virtual economy. Service manufacturization can better digest and absorb the excessive virtual bubble of assets caused by only developing service industry, it can also effectively solve the problem of low added value embedded in manufactured products due to less input of producer services. To break through the bottleneck of low-end manufacturing, integrating manufacturing servisization with service manufacturization is a good way. On the one hand, it can help not only achieve the goal of upgrading manufacturing ind ustry, but also avoid the amplified system risk caused by hollowing out because of the excessive development of service industry detached from manufacturing. This paper aims to give full play to the leading role of Yangtze River Economic Belt, help seek a sustainable strategy for regional economic development and provide an effective path to facilitate China's manufacturing 2025 and supply-side structural reforms.

\section{Literature}

The literatures related to this paper mainly focus on the integration between manufacturing and producer services[1-11]. The reference to the service economy can be traced back to futurologist Toffler's work He divided the total history of human economic development into three stages: Product Economy Era, Service Economy Era and Experience Economy Era. Then Bell proposed a similar concept of "non-industrial economy" and "post-industrial economy"[12].

At present, the major countries in the world have also begun to explore the service-oriented manufacturing, and proposed similar concept. The United States referred to service-oriented 
manufacturing as service-based manufacturing, Australia adopted service-enhanced manufacturing, Japan called it service-oriented manufacturing, and the United Kingdom named it "Product service system". All those concepts emphasize the importance of the integration between manufacturing and services. Because with the rapid development of information technology and increasing personalized consumption, traditional manufacturing has reached bottleneck of low productivity, slow technological advance, and hard to meet market demand, this shows obvious supply-side contradiction and urgently needs service-oriented manufacturing model. Service-oriented manufacturing combines knowledge, human capital, and industrial capital [13] with labor, land, and physical capital to create a new manufacturing model based on manufacturing- based services and service-based manufacturing, representing the developing direction of manufacturing upgrades of Yangtze River Economic Belt. Service-oriented manufacturing can help accomplish the integration of supply chain system, which is constructive to the coordination and cooperation of member firms in the chain, and finally realize the value of firms and customers. The value chain model of service-oriented manufacturing was summarized by Bell (1973). Network-like structure is an intrinsic feature of service-oriented manufacturing, and its successful implementation is very helpful in achieving regional linkage. However, in order to narrow the gap between regions, we must not only rely on industrial transfer, but also make great efforts to build a regional industrial chain with distinctive advantages based on their regional characteristics. Moreover, the industrial chain must be dominated by manufacturing. To order to make it, the key depends on the strong radiation effect of producer services.

Zhou (2013) and Yang (2016) have measured China's manufacturing servitization level, but have not yet studied service manufacturization rate to further realize the integration between manufacturing servitization and service manufacturization [14-15]. So based on the law of industrial evolution, considering the characteristics of Yangtze River Economic Belt, this paper aims to further study the evolution law of the integration. And then carry out comparative research based on the heterogeneity of various provinces and ind ustries. The third part of this paper will focus on the discussion of research methods. The fourth part will provide an explanation of empirical results, and finally summarize the full text and propose relevant policy recommendations.

\section{Methodology}

Under open environment, there are competition between domestic producer services and imported producer services. Thus, this paper sets two integration indices: the integration rate of manufacturing and domestic producer services and the integration rate of manufacturing and imported producer services and builds a non-competitive input-output model based on competitive input-output model of the Yangtze River Economic Belt.

In this paper, setting up non-competitive input-output model[16], Specifically, the intermediate input of competitive input-output table is scientifically subdivided into imported intermediate input and domestic intermediate input. The construction method is as follows: 
Table 1. Competitive input-output table

\begin{tabular}{|l|c|c|c|c|c|c|l|}
\hline & \multirow{2}{*}{$\begin{array}{l}\text { Intermediate } \\
\text { Use } \mathrm{i}=1,2,3 \ldots \mathrm{n}\end{array}$} & \multicolumn{2}{|l|}{ Final Use } & Import & $\begin{array}{l}\text { Total } \\
\text { Output }\end{array}$ \\
\cline { 3 - 8 } & & Consumption & Capital & Export & Total & & \\
\hline $\begin{array}{l}\text { Intermediate } \\
\text { Input } \\
\mathrm{j}=1,2,3 \ldots \mathrm{n}\end{array}$ & $X_{i j}$ & $C_{i}$ & $K_{i}$ & $E X_{i}$ & $Y_{i}$ & $M_{i}$ & $X_{i}$ \\
\hline Added Value & $V_{j}$ & & & & & & \\
\hline Total Input & $X_{j}$ & & & & & & \\
\hline
\end{tabular}

Table 2. Non-competitive input-output table

\begin{tabular}{|l|c|c|c|c|c|c|c|}
\hline & \multirow{2}{*}{$\begin{array}{l}\text { Intermediate Use } \\
\mathrm{i}=1,2,3 \ldots \mathrm{n}\end{array}$} & \multicolumn{2}{|l|}{ Final Use } & Import & $\begin{array}{l}\text { Total } \\
\text { Output }\end{array}$ \\
\cline { 3 - 8 } & $X_{i j}^{d}$ & $C_{i}^{d}$ & $K_{i}^{d}$ & $E X_{i}^{d}$ & $Y_{i}^{d}$ & $M_{i}$ & $X_{i}$ \\
\hline $\begin{array}{l}\text { Domestic } \\
\text { Intermediate } \\
\text { Input j=1,2,3...n }\end{array}$ & $X_{i j}^{m}$ & $C_{i}^{m}$ & $K_{i}^{m}$ & $E X_{i}^{m}$ & $Y_{i}^{m}$ & & \\
\hline $\begin{array}{l}\text { Imported } \\
\text { Intermediate } \\
\text { Inputj=1,2,3...n }\end{array}$ & $V_{j}$ & & & & & & \\
\hline Added Value & $X_{j}$ & & & & & & \\
\hline Total Input & & & & & & & \\
\hline
\end{tabular}

It can be seen that Table 2 is made by dividing the intermediate input of Table 1 into two parts: domestic intermediate input and imported intermediate input. This bases on the assumption that imported intermediate products are homogenous to domestic intermediate products, and hence perfect substites. Therefore, the variables relation in Table 1 and Table 2 are demonstrated by the following equations:

$$
\begin{aligned}
& X_{i j}^{d}+X_{i j}^{m}=X_{i j} \\
& C_{i}^{d}+C_{i}^{m}=C_{i} \\
& K_{i}^{d}+K_{i}^{m}=K_{i} \\
& E X_{i}^{d}+E X_{i}^{m}=E X_{i} \\
& Y_{i}^{d}+Y_{i}^{m}=Y_{i}
\end{aligned}
$$

At the same time, the deduction process from table1 to table 2 is showed by the following equations:

$$
\begin{aligned}
& Y_{i}^{m}=M_{i} \frac{Y_{i}}{\sum_{j=1}^{n} X_{i j}+Y_{i}} \\
& C_{i}^{m}=\frac{C_{i}}{Y_{i}} Y_{i}^{m}
\end{aligned}
$$




$$
\begin{aligned}
& K_{i}^{m}=\frac{K_{i}}{Y_{i}} Y_{i}^{m} \\
& E X_{i}^{m}=\frac{E X_{i}}{Y_{i}} Y_{i}^{m} \\
& Y_{i}^{m}=C_{i}^{m}+K_{i}^{m}+E X_{i}^{m}
\end{aligned}
$$

Imported intermediate input:

$$
\begin{gathered}
\sum_{j=1}^{n} X_{i j}^{m}=M_{i} \frac{\sum_{j=1}^{n} X_{i j}}{\sum_{j=1}^{n} X_{i j}+Y_{i}} \\
X_{i j}^{m}=\left(\sum_{j=1}^{n} X_{i j}^{m}\right) \frac{X_{i j}}{\sum_{j=1}^{n} X_{i j}}
\end{gathered}
$$

Domestic intermediate input:

$$
X_{i j}^{d}=X_{i j}-X_{i j}^{m}
$$

Import:

$$
M_{i}=\sum_{j=1}^{n} X_{i j}^{m}+Y_{i}^{m}
$$

It can be seen that the process of table 1 converted to table 2 is that of competitive input-output table converted to non-competitive input-output table.

Therefore, competitive input-output table is transformed into a non-competitive input-output model, which results in two subdivision tables. According to Park's measurement method[8], here construct innovatively manufacturing servitization rate and service manufacturization rate, and then multiply the two index to obtain the integration rate of manufacturing and producer services. and further subdivide it into integration rate of manufacturing and imported producer services and integration rate of manufacturing and domestic producer services. The specific process is listed as follows:

\subsection{The construction of manufacturing servitization index}

The intermediate consumption coefficient is also called the intermediate input coefficient. $\mathrm{j}$ industry 's consumption volume of $\mathrm{i}$ industry' $\mathrm{s}$ services divides the total input of $\mathrm{j}$ industry arriving:

$$
a_{i j}=x_{i j} / x_{j}
$$

$a_{i j}$ is the i industry' s consumption volume of $\mathrm{j}$ industry in the input-output table. We can further subdivide the intermediate consumption coefficient into import and domestic parts:

$$
\begin{aligned}
& a_{i j}^{D}=x_{i j}^{D} / x_{j}^{D} \\
& a_{i j}^{M}=x_{i j}^{M} / x_{j}^{M}
\end{aligned}
$$

The manufacturing servitization rate is the ratio of certain industry 's input coefficient to total industries' input coefficients in manufacturing process. It is expressed as:

$$
\begin{aligned}
& b_{i j}=a_{i j} / \sum_{i} a_{i j} \\
& \mathrm{~b}_{\mathrm{ij}}^{\mathrm{D}}=\mathrm{a}_{\mathrm{ij}}^{\mathrm{D}} / \sum_{\mathrm{i}} \mathrm{a}_{\mathrm{ij}}^{\mathrm{D}} \\
& \mathrm{b}_{\mathrm{ij}}^{\mathrm{M}}=\mathrm{a}_{\mathrm{ij}}^{\mathrm{M}} / \sum_{\mathrm{i}} \mathrm{a}_{\mathrm{ij}}^{\mathrm{M}}
\end{aligned}
$$


Among them, $\sum a_{i j}$ represents the total consumption amount of intermediate inputs for producing $\mathrm{j}, b_{i j}$ indicates the degree of dependence of $\mathrm{j}$ industry on $\mathrm{i}$ industry, and the dependence level reflects the degree of conversion of $j$ industry to $i$ industry. $b_{i j}^{D_{i j}}$ indicates the degree of conversion of domestic $j$ industry to $i$ ind ustry; $b_{i j}^{M}$ indicates the degree of conversion of imported $j$ industry to $\mathrm{i}$ industry. And $\mathrm{j}$ industry mainly refers to manufacturing industry, and i industry is service ind ustry. This paper intends to use this way to measure the manufacturing servitization rates of the Yangtze River Economic Belt.

\subsection{The construction of service manufacturization index}

$\mathrm{i}$ industry 's output volume of $\mathrm{j}$ industry' s services divides the total output of $\mathrm{i}$ industry arriving:

$\mathrm{d}_{i j}=x_{i j} / x_{i}$

Dividing it to domestic and import parts:

$d_{i j}^{D}=x_{i j}^{D} / x_{i}^{D}$

$\mathrm{d}_{\mathrm{ij}}^{\mathrm{M}}=\mathrm{x}_{\mathrm{ij}}^{\mathrm{M}} / \mathrm{x}_{\mathrm{i}}^{\mathrm{M}}$

Among them $d_{i j}$ is $\mathrm{j}$ industry's consumption amount of $\mathrm{i}$ industry in the no-competitive input-output table. $\mathrm{d}_{\mathrm{ij}}^{\mathrm{D}}$ is domestic $\mathrm{j}$ industry's consumption amount of $\mathrm{i}$ industry in the no-competitive input-output table. $\mathrm{d}_{\mathrm{ij}}^{\mathrm{M}}$ is imported $\mathrm{j}$ industry's consumption amount of $\mathrm{i}$ industry in the no-competitive input-output table.

The service manufacturization rate is the ratio of certain industry' $s$ demand coefficient to total industries' demand coefficients. It is expressed as:

$$
\begin{aligned}
& f_{i j}=d_{i j} / \sum_{j} d_{i j} \\
& \mathrm{f}_{\mathrm{ij}}^{\mathrm{D}}=\mathrm{d}_{\mathrm{ij}}^{\mathrm{D}} / \sum_{\mathrm{j}} \mathrm{d}_{\mathrm{ij}}^{\mathrm{D}} \\
& \mathrm{f}_{\mathrm{ij}}^{\mathrm{M}}=\mathrm{d}_{\mathrm{ij}}^{\mathrm{M}} / \sum_{\mathrm{j}} \mathrm{d}_{\mathrm{ij}}^{\mathrm{M}}
\end{aligned}
$$

Among them, $\sum d_{i j}$ represents $\mathrm{i}$ industry's total supply to all intermediate demands. $\sum_{\mathrm{j}} \mathrm{d}_{\mathrm{ij}}^{\mathrm{D}}$ ind icates $i$ ind ustry's total supply to all domestic intermed iate demands; $\sum_{j} d_{i j}^{M}$ indicates $i$ industry's total supply to all imported intermediate demands; $f_{i j}$ is the degree of dependence of $i$ ind us try on $j$ ind ustry, and the dependence level reflects the degree of conversion of $\mathrm{i}$ ind ustry to $\mathrm{j}$ industry. The $\mathrm{i}$ industry here mainly refers to service industry, and $\mathrm{j}$ industry is manufacturing ind ustry. This paper uses $\mathrm{f}_{\mathrm{ij}}$ to measure the service manufacturization rate in the 9 provinces and 2 cities of the Yangtze River Economic Belt. And $\mathrm{f}_{\mathrm{ij}}^{\mathrm{D}}$ measures the domestic service manufacturization rate, $\mathrm{f}_{\mathrm{ij}}^{\mathrm{M}}$ measures the imported one.

\subsection{The construction of the integration rate of manufacturing and services.}

$$
\begin{aligned}
& m_{i j}=b_{i j} * f_{i j} \\
& \mathrm{~m}_{\mathrm{ij}}^{\mathrm{D}}=\mathrm{b}_{\mathrm{ij}}^{\mathrm{D}} * \mathrm{f}_{\mathrm{ij}}^{\mathrm{D}} \\
& \mathrm{m}_{\mathrm{ij}}^{\mathrm{M}}=\mathrm{b}_{\mathrm{ij}}^{\mathrm{M}} * \mathrm{f}_{\mathrm{ij}}^{\mathrm{M}}
\end{aligned}
$$

$m_{i j}$ indicates the integration rate between manufacturing and services in the Yangtze River Economic Belt; $b_{i j}$ is manufacturing servitization rate; $f_{i j}$ is service manufaturization rate. $b_{i j}^{\mathrm{D}}$ is domestic manufacturing servitization rate, $b_{i j}^{M}$ is imported manufacturing servitization. $f_{i j}^{D}$ is domestic service manufaturization rate, $\mathrm{f}_{\mathrm{ij}}^{\mathrm{M}}$ is imported service manufaturization rate. $\mathrm{m}_{\mathrm{ij}}^{\mathrm{D}}$ is the integration rate between manufacturing and domestic services, and $\mathrm{m}_{\mathrm{ij}}^{\mathrm{M}}$ is the integration rate 
between manufacturing and imported services.

\section{Results}

Based on the measurement in the second part, a heterogeneous comparison - provincial comparison and industrial comparison- on the integration between manufacturing and producer services of Yangtze River Delta will be conducted. Based on WIOD classification, manufacturing sector is subdivided into 16 sub-industries, including food and tobacco products, textiles, wearing apparel and leather products, wood processing products and furniture, paper,printing and recreational and educational products, coke, refined petroleum products and nuclear fuel processing products, chemical products, non-metallic mineral products, metal smelting and rolling processing products, metal products, general and specialized equipment, transport equipment, electrical machinery and equipment, instrumentation,communication devices,computer and other electronic products, other manufactured products, waste cycling, manufacture and supply of water, gas, electricity and heat. The producer service sector consists of six industries, namely wholesale and retail, transport、warehousing postal services, computer software and information services, finance, leasing and business services, scientific research and technological services. According to the method of Yang Ling[9], this paper subdivides producer service into high-, medium- and low-tech density. Finance, scientific research and technical services are included in high-tech density category; Computer software and information services, leasing and business services are classified into medium-tech density category; Transport, warehousing, postal services and wholesale and retail industry belong to low-tech density category. This paper adopts input-output table data of 11 provinces of Yangtze River Economic Belt in 2002, 2007 and 2012 to conducts an empirical study.

The integration rate of manufacturing and producer services is a comprehensive index to measure the integration level of manufacturing servitization and service manufacturization. We break total producer services into domestic producer services and imported producer services. So we can compare integration rate of manufacturing servitization and imported service manufacturization and that of manufacturing servitizaion and domestic service manufacturization to get some heterogeneous features.

4.1 A heterogeneous comparative study on the integration between manufacturing and wholesale and retail services.

Wholesale and retail industry is a crucial part of socialized mass production. It plays an important role in guiding economic development speed, quality and efficiency. And it is one of the ind ustries with high degree of marketization and fierce competition in China. We use non-competitive inputoutput model to subdivide the wholesale and retail services into two parts, domestic and imported. The breakdown of it is as follows: 
Table 3. The integration between manufacturing and domestic wholesale and retail services.

\begin{tabular}{|c|c|c|c|c|c|c|c|c|c|c|c|}
\hline \multicolumn{12}{|c|}{$\begin{array}{c}\text { The integration rate between manufacturing and domestic wholesale and retail services in } 11 \text { provinces of the } \\
\text { Yangtze River Economic Belt }\end{array}$} \\
\hline 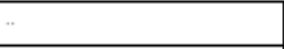 & Anhui. & Guizhou, & Hubei. & Hunan. & Jiangsu & \begin{tabular}{|l|} 
Jiangxi. \\
\end{tabular} & Shanghai. & Sichuan & Yunnan. & Zhejiang. & Chongqing: \\
\hline food and to & 0.1597. & 0.0240 & 0.0335 & 1075 & 0000 & 0.1355 & 0.0184 & .0762 & 1.0383. & 0.0206 & 0.0675 \\
\hline $\begin{array}{l}\text { tertiles, wearing apparel } \\
\text { and leather products. }\end{array}$ & 0510 & 0.0045 & 0.0411 & .0295 & 0.0249 & 0.1549 & 0.0347. & 0.0248 & 0.0026 & 0.2254 & 0.0347 \\
\hline $\begin{array}{l}\text { wood processing products and } \\
\text { fumiture. }\end{array}$ & 0.0121 & 0.0000 & 0.0055 & 0.0205 & 0.1414 & 0.0121 & 0.0085 & 0.0099 & 0.0054 & 0.0100 & 0.0024 \\
\hline $\begin{array}{l}\text { paper, printing and } \\
\text { recreational and educational } \\
\text { products. }\end{array}$ & 0.0115 & 0.0056 & 0.0106 & 0.0225 & 0.0000 & 0.0273 & . & 0113 & 0.0194 & 65. & 2271. \\
\hline $\begin{array}{l}\text { coke, refined petroleum } \\
\text { products and nuclear fuel } \\
\text { processing products. }\end{array}$ & 0.0078 & 0.0173 & 0.0105 & 0.0294 & 0.0009 & 0.0093 & 0.0005 & 0.0055 & 0.0069 & 0.0180 & 0.0002 \\
\hline chemical products. & 0.0373 & 0.0399 & 0.0271 & 0.0892 & 0.0439 & \begin{tabular}{|l|}
0.0808 \\
\end{tabular} & 0.0513. & 0.0383 & 0.0705 & 0.0329 & 0.0160 \\
\hline non-metallic mineral products. & 0.0134 & 0.0103. & 0.0089 & 0.0388 & 0.0566 & 0.0294 & 0.0094 & 0.0222. & 0.0284 & 0.0105 & 0.0027. \\
\hline $\begin{array}{l}\text { metal smelting and rolling } \\
\text { processing products. }\end{array}$ & 0.0460 & 0.1227 & 0.0086 & 0.1107 & 0.0003 & 0.0233 & 0.0021 & 0.0152 & 0.1086 & 0.0082 & 0.0016 \\
\hline metal products. & 0154. & 150. & 0.0254 & 185. & 0.2384 & 0.0024 & & & 94. & & 0021. \\
\hline $\begin{array}{l}\text { general and specialized } \\
\text { equipment. }\end{array}$ & 0.0515 & 0.0062 & 0.0251 & 0.1180 & 0.0080 & 0.0107 & 0.0383 & 0.0384 & 0.0116 & 0.0155 & 0.0115 \\
\hline $\begin{array}{l}\text { instrumentation } \\
\text { communication devices, } \\
\text { computer and other electronic } \\
\text { products. }\end{array}$ & 0.0228 & 0.0036 & 0.0575 & 0.0318 & 0.0000 & 0.0302 & 0.1120 & 0.0368 & 0.0029 & 0.0198 & 0.1252 \\
\hline $\begin{array}{l}\text { electrical machinery and } \\
\text { equipment. }\end{array}$ & 0.0878 & 0.0129 & 0.0240 & 0.0255 & 0.0942 & 0.0223 & 0.0437 .1 & 0.0110 & 0.0068 & 0.0182 & 0.0129 \\
\hline transport equipment. & 0.0500. & 0.0203 .1 & 0.0206 & 0.0356 & 0.1171 & \begin{tabular}{|l|}
0.0237 \\
\end{tabular} & 0.1213 .1 & 0.0278 & 0.0104 & 0.0116. & 0.1458 \\
\hline other manufactured products. & 0.0012 & 0.0103. & 0.0009 & 0.0032 & 0.0000 & 0.0017 & 0.0023 & 0.0006 & 0.0002 & 0.0022 & 0.0017 \\
\hline waste cycling. & 0.0000 & 0.0000 & 0.0002 & 0.0010 & 0.0000 & 0.0002 & 0.0000. & 0.0001 & 0.0000 & 0.0030. & 0.0007 \\
\hline $\begin{array}{l}\text { manufacture and supply of } \\
\text { water, gas, electricity and } \\
\text { heat. }\end{array}$ & 0.0100 & 0.0133 & 0.0446 & 0.0458 & 0.0485 & 0.0009 & 0.0003. & 0.0143 & 0.0660 & 0.0019 & 0.0000 \\
\hline
\end{tabular}


It can be seen that the integration of domestic wholesale and retail services and manufacturing is relatively good, especially highlighting the advantages of ind ustries with local characteristics. We must continue to maintain and adhere to this, because the rapid development of ind ustries with local characteristics will play a supportive role in accelerating the long-term and stable growth of local economy. But overcapacity caused by repeated investment should be avoided. In next step, we should introduce relevant policies to further encourage and strengthen the development of industries with local characteristics. This will be advantageous to regional economic growth as well as industrial upgrade. As the hometown of silk in the Yangtze River Economic Belt, Zhejiang has a high degree of integration level between textiles, wearing apparel and leather products ind ustry and domestic wholesale and retail services, reaching 0.1414 , ranking first in the 11 provinces of the Yangtze River Economic Belt.

At the same time, Jiangsu, as a relatively developed province in the Yangtze River economic belt, whose manufacturing has a relatively high degree of integration level with domestic wholesale and retail services, including wood processing products and furniture, non-metallic mineral products, metal products, electrical machinery and equipment, reflecting that Jiangsu is characterized by manufacturing industry cluster, such as industrial park. At the same time, Hunan province, located in the midstream Yangtze River Economic Belt, whose integration between manufacturing and domestic wholesale and retail services is ranked first in the 11 provinces, including coke, refined petroleum products and nuclear fuel processing products, chemical products, general and specialized equipment. At the same time, Chongqing, as China's important industrial land, has good integration between its manufacturing and domestic wholesale and retail services, including instrumentation, communication devices, computers and other electronic equipment, transport equipment represented by Lifan, Jialing Motorcycle. Because of the relatively rich mineral resources in Guizhou, metal smelting and rolling processing products are relatively well integrated with domestic wholesale and retail. Anhui's integration between food and tobacco industry and domestic wholesale and retail services is relatively high, ranking first in the Yangtze River Economic Belt. As a whole, the integration level between industries with local characteristics and domestic wholesale and retail services is relatively high, which is one of the reflections of the integration between low-tech services and manufacturing. 
Table 4. The integration between manufacturing and imported wholesale and retail services

\begin{tabular}{|c|c|c|c|c|c|c|c|c|c|c|c|}
\hline \multicolumn{12}{|c|}{$\begin{array}{l}\begin{array}{l}\text { The integration rate between manufacturing and imported wholesale and retail services in } 11 \text { provinces of the } \\
\text { Yangtze River Economic Belt }\end{array} \\
\end{array}$} \\
\hline .. & Anhui. & Guizhou. & Hubei. & Hunan. & Jiangsu. & Jiangxi. & Shanghai. & Sichuan. & Yunnan. & Zhejiang, & Chongqing \\
\hline food and tobacco products. & 0.0000 & 0.0000 & 0.0000 & 0.0000 & 0.0000 & 0.0000 & 0.0000 & 0.0000 & 0.0000 & 0.0000 & 0.0000 \\
\hline $\begin{array}{l}\text { textiles. wearing apparel } \\
\text { and leather products. }\end{array}$ & 0.0000 & 0.0000 & 0.0000 & 0.0000 & 0.0000 & 0.0000 & 0.0000 & 0.0000 & 0.0000 & 0.0000 & 0.0000 \\
\hline $\begin{array}{l}\text { wood processing products and } \\
\text { furniture. }\end{array}$ & 0.0000 & 0.0000 & 0.0000 & 0.0000 & 0.0000 & 0.0000 & 0.0000 & 0.0000 & 0.0000 & 0.0000 & 0.0000 \\
\hline $\begin{array}{l}\text { paper. printing and } \\
\text { recreational and educational } \\
\text { products. }\end{array}$ & 0.0000 & 0.0000 & 0.0000 & 0.0000 & 0.0000 & 0.0000 & 0.0000 & 0.0000 & 0.0000 & 0.0000 & 0.0000 \\
\hline $\begin{array}{l}\text { coke, refined petroleum } \\
\text { products and nuclear fuel } \\
\text { processing products. }\end{array}$ & 0.1778 & 0.1859 & 0.0170 & 0.0430 & 0.0154 & 0.1311 & 0.0561 & 0.0442 & 0.0057 & 0.0211 & 0.0356 \\
\hline chemical products. & 0.0025 & 0.0066 & 0.0012 & 0.0021 & 0.0000 & 0.0065 & 0.0012 & 0.0002 & 0.0014 & 0.0049 & 0.0240 \\
\hline non-metallic mineral products. & 0.0000 & 0.0000 & 0.0000 & 0.0000 & 0.0000 & 0.0000 & 0.0000 & 0.0000 & 0.0000 & 0.0000 & 0.0000 \\
\hline $\begin{array}{l}\text { metal smelting and rolling } \\
\text { processing products. }\end{array}$ & 0.0000 & 0.0000 & 0.0000 & 0.0000 & 0.0000 & 0.0000 & 0.0000 & 0.0000 & 0.0000 & 0.0000 & 0.0000 \\
\hline metal products. & 0.0161 & 0.2437 & 0.0095 & 0.0186 & 0.0167 & 0.0308 & 0.0117 & 0.0130 & 0.0066 & 0.0175 & 0.0173 \\
\hline $\begin{array}{l}\text { general and specialized } \\
\text { equipment. }\end{array}$ & 0.0000 & 0.0000 & 0.0000 & 0.0000 & 0.0000 & 0.0000 & 0.0000 & 0.0000 & 0.0000 & 0.0000 & 0.0000 \\
\hline $\begin{array}{l}\text { instrumentation } \\
\text { communication devices, } \\
\text { computer and other electronic } \\
\text { products. }\end{array}$ & 0.0000 & 0.0000 & 0.0000 & 0.0000 & 0.0000 & 0.0000 & 0.0000 & 0.0000 & 0.0000 & 0.0000 & 0.0000 \\
\hline $\begin{array}{l}\text { electrical machinery and } \\
\text { equipment. }\end{array}$ & 0.0000 & 0.0000 & 0.0000 & 0.0000 & 0.0000 & 0.0000 & 0.0000 & 0.0000 & 0.0000 & 0.0000 & 0.0000 \\
\hline transport equipment. & 0.0000 & 0.0000 & 0.0000 & 0.0000 & 0.0000 & 0.0000 & 0.0000 & 0.0000 & 0.0000 & 0.0000 & 0.0000 \\
\hline other manufactured products. & 0.0000 & 0.0000 & 0.0000 & 0.0000 & 0.0000 & 0.0000 & 0.0000 & 0.0000 & 0.0000 & 0.0000 & 0.0000 \\
\hline waste cycling, & 0.1778 & 0.1859 & 0.0170 & 0.0430 & 0.0154 & 0.1311 & 0.0561 & 0.0442 & 0.0057 & 0.0211 & 0.0356 \\
\hline $\begin{array}{l}\text { manufacture and supply of } \\
\text { water. gas. electricity and } \\
\text { heat. }\end{array}$ & 0.0025 & 0.0066 & 0.0012 & 0.0021 & 0.0000 & 0.0065 & 0.0012 & 0.0002 & 0.0014 & 0.0049 & 0.0240 \\
\hline
\end{tabular}

Wholesale and retail services, as an important channel for marketing, play a vital role in the rapid entry of products into a local market and is directly relevant to the optimization of regional business environment. In 2012, there is a certain degree of integration between manufacturing and imported wholesale and retail services in Zhejiang, Jiangxi, and Shanghai while the import amount of wholesale and retail services in other provinces is zero. Specially, some sub-industries' integration with imported wholesale and retail services is slightly higher in Jiangxi, including food and tobacco, textiles, wearing apparel and leather products, chemical products while it is relatively low in Zhejiang and Shanghai. It is can be seen that not all provinces in the Yangtze River Economic Belt import wholesale and retail services. Compared with domestic wholesale and retail services, the imported wholesale and retail services are poorly integrated with manufacturing in the Yangtze River Economic Belt. On the one hand, it shows that service industry needs more opening up; on the other hand, it shows our cautious attitude towards importing producer services overseas. Unlike the physical industries such as agriculture and manufacturing, the opening up of service sector has a long-term impact on a country's security. For example, the improper opening up of Thai's finance had a huge negative impact on its security. Therefore, it is definitely necessary to increase imported producer services, but at the same time, we need to make domestic producer services a step ahead and allow them to have sufficient room for growth.

4.2 A he terogeneous comparative study on the integration between manufacturing and transport、 warehousing and postal services 
As an important channel for invigorating the economy, transport w warehousing and postal services weigh heavily for manufactured products, raw materials and supply chains. They have strong influence and induced power [12], which facilitates running efficiency of manufacturing sector.

Table 5. The integration between manufacturing and domestic transport、 warehousing and postal services

The integration rate between manufacturing and domestic transport、warehousing and postal +

services in 11 provinces of the Yangtze River Economic Belt

\begin{tabular}{|c|c|c|c|c|c|c|c|c|c|c|c|}
\hline & Ankui, & Guizhou. & Hubei. & Hunan. & Jiangsu & Jizngxi. & Shanghai. & Sichuan. & Yumnan. & Zhejiang, & Chongqing \\
\hline food and tobacco products. & 0.0159 & 0.0335 & 0.0455 & 0.0145 & 0.0525 & 0.0138 & 0.0080 & 0.0181 & 0.0831 & 0.0153 & 0.0243 \\
\hline $\begin{array}{l}\text { tertiles, wearing apparel } \\
\text { and leather products. }\end{array}$ & 0.0067 & 0.0015 & 0.0151 & 0.0019 & 0.1141 & 0.0052 & 0.0020 & 0.0030 & 0.0010 & 0.0096 & 0.0027. \\
\hline $\begin{array}{l}\text { wood processing products and } \\
\text { funiture. }\end{array}$ & 0.0082 & 0.0026 & 0.0019 & 0.0011 & 0.0752 & 0.0047 & 0.0032 & 0.0033. & 0.0028 & 0.0106 & 0.0032 \\
\hline $\begin{array}{l}\text { paper, printing and } \\
\text { recreational and educational } \\
\text { products. }\end{array}$ & 0.0063 & 0.0018 & 0.0125 & 0.0003 & 0.0838 & 0.0086 & 0.0063 & 0.0021 & 0.0032 & 0.0111 & 0.0016 \\
\hline $\begin{array}{l}\text { coke, refined petroleum } \\
\text { products and nuclear fuel } \\
\text { processing products. }\end{array}$ & 0.0039 & 0.0110 & 0.0001 & 0.0000 & 0.0368 & 0.0056 & 0.0017 & 0.0007 & 0.0645 & 0.0021 & 0.0116 \\
\hline chemical products. & 0.0533 & 0.0995. & 0.0620 & 0.0130 & 0.0664 & 0.0332 & 0.0372 & 0.0515 & 0.0271 & 0.0429 & 0.0353 \\
\hline non-metallic mineral prociucts. & 0.0440 & 0.0399 & 0.0553 & 0.0044 & 0.1891 & 0.0243 & 0.0056 & 0.0262. & 0.0178 & 0.0269 & 0.0459 \\
\hline $\begin{array}{l}\text { metal smelting and rolling } \\
\text { processing products. }\end{array}$ & 0.0348 & 0.1144 & 0.0068 & 0.0025 & 0.1295 & 0.0813 & 0.0072 & 0.0176 & 0.0651 & 0.0099 & 0.0461 \\
\hline metal products. & 0.0064 & 0.0023. & 0.0045 & 0.0013 & 0.0313 & 0.0109 & 0.0082 & 0.0118 & 0.0014 & 0.0104 & 0.0082 \\
\hline $\begin{array}{l}\text { geveral and specialized } \\
\text { equipment. }\end{array}$ & 0.0127 & 0.0028 & 0.0166 & 0.0090 & 0.0867 & 0.0080 & 0.0272 & 0.0159 & 0.0027 & 0.0184 & 0.0201 \\
\hline $\begin{array}{l}\text { instrumentation } \\
\text { communication devices, } \\
\text { computer and other electronic } \\
\text { products. }\end{array}$ & 0.0040 & 0.0019 & 0.0020 & 0.0010 & 0.0616 & 0.0019 & 0.0054 & 0.0080 & 0.0003 & 0.0034 & 0.0032 \\
\hline $\begin{array}{l}\text { electrical machinery and } \\
\text { equipment. }\end{array}$ & 0.0132 & 0.0034 & 0.0072 & 0.0059 & 0.0879 & 0.0086 & 0.0079 & 0.0082 & 0.0011 & 0.0093. & 0.0108 \\
\hline tramsport equipment. & 0.0086 & 0.0059 & 0.0549 & 0.0009 & 0.0109 & 0.0031 & 0.0087. & 0.0044 & 0.0011 & 0.0084 & 0.0923. \\
\hline other manufactured prodicts. & 0.0018 & 0.0003. & 0.0026 & 0.0012 & 0.1672 & 0.0001 & 0.0010 & 0.0010 & 0.0001 & 0.0034 & 0.0008 \\
\hline waste cycling. & 0.0024 & 0.0001 & 0.0058 & 0.0000 & 0.5534 & 0.0003 & 0.0005 & 0.0005 & 0.0000 & 0.0008 & 0.0038 \\
\hline $\begin{array}{l}\text { manufacture and supply of } \\
\text { water, gas, electricity and } \\
\text { heat. }\end{array}$ & 0.0646 & 0.0584 & 0.0021 & 0.0040 & 0.1434 & 0.3312 & 0.0212 & 0.0056 & p.0009. & 0.0166 & 0.0037. \\
\hline
\end{tabular}

Jiangsu, a downstream province of the Yangtze River Economic Belt, has a good performance in the integration between domestic transport、warehousing and postal services and manufacturing. Specially, those are textiles, wearing apparel and leather products, wood processing products and furniture, paper, printing and cultural and educational goods, non-metallic mineral products, metal smelting and rolling processing products, metal products, general and specialized equipment, instrumentation, communication devices, computers and other electronic equipment, electrical machinery and equipment, other manufactured products, and waste recycling industry. Furthermore, the national logistics center represented by Kunshan in Jiangsu, has a strong capacity for domestic and cross-border logistics transportation. Its integration with manufacturing industry gives full play to transport, warehousing and postal services, which is considerably helpful for the rapid development of Jiangsu's major industries. In particular, it promotes concentration effect of re gional producer services and drives the development of industries with regional characteristics. However, considering the current integration level, there is still great potential for further improvement. 
Table 6. The integration between manufacturing and imported transport, warehousing and postal services

The integration rate between manufacturing and imported transport、warehousing and postal

services in 11 provinces of the Yangtze River Economic Belt.

\begin{tabular}{|c|c|c|c|c|c|c|c|c|c|c|c|}
\hline+ & Avhui. & Guizhou: & Hubei. & Human & Jianger. & Jiangyi. & Shanghai & Sichuan & Yurnam. & Zhejimg. & Chongqing \\
\hline food and tobecco products. & 0.0000 & 0.0000 & 0.0227 & 0.0000 & 0.0075 & 0.0269 & 0.0000 & 0.0000 & 0.0117 & 0.0039 & 0.0000 \\
\hline $\begin{array}{l}\text { textiles, wearing apporel } \\
\text { and leather products. }\end{array}$ & 0.0000 & 0.0000 & 0.0029 & 0.0000 & 0.0026 & 0.0092 & 0.0000 & 0.0000 & 0.0102 & 0.0006 & 0.0000 \\
\hline $\begin{array}{l}\text { wood processing products and } \\
\text { fumitue. }\end{array}$ & 0.0000 & 0.0000 & 0.0025 & 0.0000 & 0.0027 & 0.0113 & 0.0000 & 0.0000 & 0.0098 & 0.0008 & 0.0000 \\
\hline $\begin{array}{l}\text { paper, printing and } \\
\text { recreztional and educational } \\
\text { products. }\end{array}$ & 0.0000 & 0.0000 & 0.0035 & 0.0000 & 0.0055 & 0.0220 & 0.0000 & 0.0000 & 0.0123 & 0.0005 & 0.0000 \\
\hline $\begin{array}{l}\text { colke, refived petroleum } \\
\text { prodists and ruclear fuel } \\
\text { processing products. }\end{array}$ & 0.0000 & 0.0000 & 0.0025 & 0.0000 & 0.0038 & 0.0045 & 0.0000 & 0.0000 & 0.0019 & 0.0022 & 0.0000 \\
\hline chemical products. & 0.0000 & 0.0000 & 0.0152 & 0.0000 & 0.0221 & 0.1159 & 0.0000 & 0.0000 & 0.0392 & 0.0044 & 0.0000 \\
\hline non-metallic mineral products, & 0.0000 & 0.0000 & 0.0072 & 0.0000 & 0.0190 & 0.0183 & 0.0000 & 0.0000 & 0.0294 & 0.0100 & 0.0000 \\
\hline $\begin{array}{l}\text { metal smelting and rolling } \\
\text { processing procucts. }\end{array}$ & 0.0000 & 0.0000 & 0.0020 & 0.0000 & 0.0634 & 0.0202 & 0.0000 & 0.0000 & 0.0154 & 0.0090 & 0.0000 \\
\hline metal produxts. & 0.0000 & 0.0000 & 0.0014 & 0.0000 & 0.0103 & 0.0260 & 0.0000 & 0.0000 & 0.0117 & 0.0010 & 0.0000 \\
\hline $\begin{array}{l}\text { general and specizlized } \\
\text { equipment. }\end{array}$ & 0.0000 & 0.0000 & 0.0056 & 0.0000 & 0.0065 & 0.0861 & 0.0000 & 0.0000 & 0.0204 & 0.0037 & 0.0000 \\
\hline $\begin{array}{l}\text { instrumestrtion } \\
\text { commurication devices, } \\
\text { computer and ocher electronic } \\
\text { products. }\end{array}$ & 0.0000 & 0.0000 & 0.0007 & 0.0000 & 0.0009 & 0.0284 & 0.0000 & 0.0000 & 0.0029 & 0.0014 & 0.0000 \\
\hline $\begin{array}{l}\text { electrical nachinery and } \\
\text { equipment. }\end{array}$ & 0.0000 & 0.0000 & 0.0045 & 0.0000 & 0.0060 & 0.0326 & 0.0000 & 0.0000 & 0.0082 & 0.0009 & 0.0000 \\
\hline tramsport equipment. & 0.0000 & 0.0000 & 0.0018 & 0.0000 & 0.0019 & 0.0407 & 0.0000 & 0.0000 & 0.0092 & 0.0140 & 0.0000 \\
\hline otber mamufictured products. & 0.0000 & 0.0000 & 0.0027 & 0.0000 & 0.0000 & 0.0034 & 0.0000 & 0.0000 & 0.0027 & 0.0001 & $0.0000=$ \\
\hline waste cycling, & 0.0000 & 0.0000 & 0.0000 & 0.0000 & 0.0003 & 0.0011 & 0.0000 & 0.0000 & 0.0008 & 0.0050 & 0.0000 \\
\hline $\begin{array}{l}\text { manufacture and surply of } \\
\text { wzter, gas, electricity abd } \\
\text { heat. }\end{array}$ & 0.0000 & 0.0000 & 0.0008 & 0.0000 & 0.3512 & 0.0480 & 0.0000 & 0.0000 & 0.0271 & 0.0006 & 0.0000 \\
\hline
\end{tabular}

The integration between imported transport, warehousing and postal services and manufacturing only exists in Hunan, Jiangxi, Chongqing and Shanghai in the Yangtze River Economic Belt and it is in a low level. Specifically, the integration level between food and tobacco and imported transport, warehousing and postal services in Hunan is 0.0227, Jiangxi is only 0.0075, Zhejiang is 0.0117, and Shanghai is 0.0269 . There are much room for further improvement. If we do not distinguish domestic producer services with imported producer services, it is impossible to discover the heterogeneous difference between them. This is one of the contributions of this paper.

\subsection{A he terogeneous comparative study on the integration between manufacturing and finance}

The integration between finance and physical industries has always been one of the concerns of China's economic fundamentals. This is especially the case for a small firm to gain loans from the market. Realizing the effective integration between manufacturing and finance embodies the good relationship between virtual and real economy. 
Table 7. The integration between manufacturing and domestic finance

\begin{tabular}{|c|c|c|c|c|c|c|c|c|c|c|c|}
\hline . & Anhui. & Grizhou. & Hubei. & Hunan. & Jiangou. & Jiangyi & Shanghai. & Sickuan. & Yurnman. & Zhejiang: & Chongqing. \\
\hline food and tobecco products. & 0.0052 & 0.0103 & 0.0172 & 0.0134 & 0.0276 & 0.0022 & 0.0035 & 0.0178 & 0.0082 & 0.0082 & $0.0081 \ldots$ \\
\hline $\begin{array}{l}\text { testiles. wearing aypurel } \\
\text { and leatber products. }\end{array}$ & 0.0149 & 0.0001 & 0.0098 & 0.0053 & 0.0232 & 0.0018 & 0.0018 & 0.0095 & 0.0003 & 0.0240 & x \\
\hline $\begin{array}{l}\text { wood processing proctucts and } \\
\text { fumitre. }\end{array}$ & 0.0010 & 0.0005 & 0.0023 & 0.0020 & 0.0165 & 0.0004 & 0.0008 & 0.0087 & 0.0009 & 0.0045 & $0.0012 \ldots$ \\
\hline $\begin{array}{l}\text { paper, printing and } \\
\text { recrestional and ediscational } \\
\text { products. }\end{array}$ & 0.0026 & 0.0024 & 0.0029 & 0.0061 & 0.0783 & 0.0023 & 0.0023 & 0.0124 & 0.0030 & 0.0162 & ב. \\
\hline $\begin{array}{l}\text { colke, refived petroleum } \\
\text { products and muclear fivel } \\
\text { processing products. }\end{array}$ & 0.0017 & 0.0109 & 0.0004 & 0.0005 & 0.2310 & 0.0018 & 0.0027 & 0.0057 & 0.0039 & 0.0004 & ד. \\
\hline chemical products. & 0.0153 & 0.0281 & 0.0345 & 0.0160 & 0.0510 & 0.0160 & 0.0142 & 0.0393 & 0.0157 & 0.0648 & 0.0254 \\
\hline non-metallic mineral procuscts, & 0.0075 & 0.0205 & 0.0279 & 0.0197 & 0.0280 & 0.0220 & 0.0031 & 0.0355 & 0.0240 & 0.0156 & 0.0251 \\
\hline $\begin{array}{l}\text { metal amselting and rolling } \\
\text { procesaing products. }\end{array}$ & 0.0220 & 0.0075 & 0.0313 & 0.0335 & 0.2165 & 0.0177 & 0.0304 & 0.0697 & 0.0665 & 0.0374 & 0.0578. \\
\hline metal produxts. & 0.0041 & 0.0005 & 0.0046 & 0.0026 & 0.0431 & 0.0030 & 0.0056 & 0.0043 & 0.0003 & 0.0156 & 0.0030 \\
\hline $\begin{array}{l}\text { general and specizlized } \\
\text { equipment. }\end{array}$ & 0.0129 & 0.0021 & 0.0173 & 0.0183 & 0.0586 & 0.0041 & 0.0148 & 0.0105 & 0.0016 & 0.0264 & 0.0072. \\
\hline $\begin{array}{l}\text { instrumestation } \\
\text { commurication devices. } \\
\text { computer and ocher electronic } \\
\text { produsts. }\end{array}$ & 0.0041 & 0.0001 & 0.0027 & 0.0019 & 0.0574 & 0.0001 & 0.0470 & 0.0403 & 0.0008 & 0.0052 & 0.0171. \\
\hline $\begin{array}{l}\text { electrical machinery and } \\
\text { equipement. }\end{array}$ & 0.0035 & 0.0001 & 0.0036 & 0.0050 & 0.0268 & 0.0081 & 0.0040 & 0.0055 & 0.0007 & 0.0179 & 0.0045. \\
\hline transport equipment. & 0.0256 & 0.0089 & 0.0162 & 0.0029 & 0.0299 & 0.0034 & 0.0098 & 0.0068 & 0.0006 & 0.0201 & 0.0193 \\
\hline other mamufictured products. & 0.0002 & 0.0050 & 0.0005 & 0.0002 & 0.0523 & 0.0000 & 0.0000 & 0.0003 & 0.0002 & 0.0006 & 0.0069 \\
\hline waste cycling, & 0.0005 & 0.0000 & 0.0000 & 0.0004 & 0.0012 & 0.0004 & 0.0005 & 0.0003 & 0.0000 & 0.0005 & 0.0023 \\
\hline $\begin{array}{l}\text { manufacture and surply of } \\
\text { water, gas, electricity awd } \\
\text { hezt. }\end{array}$ & 0.0271 & 0.2811 & 0.1513 & 0.0099 & 0.1187 & 0.0197 & 0.0369 & 0.0831 & 0.1735 & 0.0631 & ד. \\
\hline
\end{tabular}

The integration between manufacturing and domestic finance in Jiangsu is relatively higher than that of other provinces in the Yangtze River Economic Belt, with an average of 0.0761 , including food and tobacco, wood processing products and furniture, paper, printing and cultural and educational goods, coke, petroleum products and nuclear fuel processing products, metal smelting and rolling processing products, metal products, general and specialized equipment, instrumentation, communication devices, computers and other electronic equipment, electrical machinery and equipment, transport equipment and other manufactured products. But the overall level is not high and there is a room for enhancement. At the same time, in Zhejiang, the integration rate of textile, wearing apparel and leather products and domestic finance reached 0.0239 and for chemical products, its integration with domestic finance is 0.0648 , ranking first in the Yangtze River Economic Belt. Moreover, Shanghai, as an international finance center, although the overall level and strength of finance is relatively strong, but the integration between domestic finance and manufacturing is still lower than that of Jiangsu Province.

Compared with Jiangsu, the deep integration between real industry and virtual ind ustry is not ideal in shanghai. Its manufacturing's integration with domestic finance is relatively low, such as food and tobacco, textile, wearing apparel and leather products, wood processing products and furniture, paper, printing and cultural and educational goods, chemical products, non-metallic mineral products, metal smelting and rolling processing products. Among them, although the industry of textile, wearing apparel and leather products is one with regional characteristics in Shanghai, its integration with domestic finance is only 0.0018, ranking the 9 th in the Yangtze River Economic Belt. From this, it is can be recommended that in the process of accelerating the construction of international finance center, Shanghai on the one hand, should also reinforce the development of finance, taking full advantages of the opening opportunity of the establishment of 
Shanghai Free Trade Zone and accelerating the development of offshore finance. On the other hand, from the results of empirical research in this paper, Shanghai should strength the integration between finance and real industries in the future, especially with advanced manufacturing. Judging from the current integration between manufacturing and domestic finance, Shanghai is lagging behind Jiangsu. In other words, the finance that Shanghai took the lead in China has signs of being separated from industrial entity. In next step, we must pay more attention to the integration between virtual and real economy and accelerate industrial technology advancement, capital circulation, equipment upgrade so that more funds can really play a role in promoting industrial progress. It is necessary to avoid excessive entry of finance into service industry. Because self-circulation detached from manufacturing causes unhealthy problems, such as excessive asset bubbles and hollowing out of real economy. This will be detrimental to the sustainable growth of Shanghai's economy.

Table 8.the integration between manufacturing and imported finance

\begin{tabular}{|c|c|c|c|c|c|c|c|c|c|c|c|}
\hline \multicolumn{12}{|c|}{$\begin{array}{l}\text { The integration rate between manufacturing and imported finance in } \\
11 \text { provinces of the Yangtze River Economic Belt }\end{array}$} \\
\hline 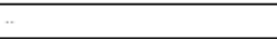 & Anhui. & Guizhou. & Hubei. & Hunan & Jiangsu. & Jiangxi. & Shanghai. & Sichuan. & Yunnan. & Zhejiang & Chongqing \\
\hline food and tobacco products. & 0.0000 & 0.0000 & 0.0651 & 0.0000 & 0.0000 & 0.0028 & 0.0000 & 0.0000 & 0.0001 & 0.0001 & 0.0000 \\
\hline $\begin{array}{l}\text { textiles, wearing apparel } \\
\text { and leather products. }\end{array}$ & 0.0000 & 0.0000 & 0.0219 & 0.0000 & 0.0000 & 0.0020 & 0.0000 & 0.0000 & 0.0002 & 0.0001 & 0.0000 \\
\hline $\begin{array}{l}\text { wood procesging products and } \\
\text { furniture. }\end{array}$ & 0.0000 & 0.0000 & 0.0069 & 0.0000 & 0.0000 & 0.0007 & 0.0000 & 0.0000 & 0.0000 & 0.0000 & 0.0000 \\
\hline $\begin{array}{l}\text { paper. printing and } \\
\text { recreational and educational } \\
\text { products. }\end{array}$ & 0.0000 & 0.0000 & 0.0217 & 0.0000 & 0.0000 & 0.0019 & 0.0000 & 0.0000 & 0.0002 & 0.0002 & 0.0000 \\
\hline $\begin{array}{l}\text { coke, refined petroleum } \\
\text { products and nuclear fuel } \\
\text { processing products. }\end{array}$ & 0.0000 & 0.0000 & 0.0048 & 0.0000 & 0.0000 & 0.0017 & 0.0000 & 0.0000 & 0.0000 & 0.0000 & 0.0000 \\
\hline chemical products. & 0.0000 & 0.0000 & 0.0467 & 0.0000 & 0.0000 & 0.0106 & 0.0000 & 0.0000 & 0.0005 & 0.0004 & 0.0000 \\
\hline non-metallic mineral products. & 0.0000 & 0.0000 & 0.0594 & 0.0000 & 0.0000 & 0.0024 & 0.0000 & 0.0000 & 0.0002 & 0.0006 & 0.0000 \\
\hline $\begin{array}{l}\text { metal smelting and rolling } \\
\text { processing products. }\end{array}$ & 0.0000 & 0.0000 & 0.0992 & 0.0000 & 0.0000 & 0.0204 & 0.0000 & 0.0000 & 0.0005 & 0.0012 & 0.0000 \\
\hline metal products. & 0.0000 & 0.0000 & 0.0074 & 0.0000 & 0.0000 & 0.0042 & 0.0000 & 0.0000 & 0.0002 & 0.0000 & 0.0000 \\
\hline $\begin{array}{l}\text { general and specialized } \\
\text { equipment. }\end{array}$ & 0.0000 & 0.0000 & 0.0574 & 0.0000 & 0.0000 & 0.0112 & 0.0000 & 0.0000 & 0.0003 & 0.0001 & 0.0000 \\
\hline $\begin{array}{l}\text { instrumentation } \\
\text { communication devices. } \\
\text { computer and other electronic } \\
\text { products. }\end{array}$ & 0.0000 & 0.0000 & 0.0075 & 0.0000 & 0.0000 & 0.0595 & 0.0000 & 0.0000 & 0.0000 & 0.0008 & 0.0000 \\
\hline $\begin{array}{l}\text { electrical machinery and } \\
\text { equipment. }\end{array}$ & 0.0000 & 0.0000 & 0.0162 & 0.0000 & 0.0000 & 0.0040 & 0.0000 & 0.0000 & 0.0001 & 0.0000 & 0.0000 \\
\hline transport equipment. & 0.0000 & 0.0000 & 0.0083 & 0.0000 & 0.0000 & 0.0110 & 0.0000 & 0.0000 & 0.0002 & 0.0003 & 0.0000 \\
\hline other manufactured products. & 0.0000 & 0.0000 & 0.0006 & 0.0000 & 0.0000 & 0.0000 & 0.0000 & 0.0000 & 0.0000 & 0.0001 & 0.0000 \\
\hline waste cycling. & 0.0000 & 0.0000 & 0.0012 & 0.0000 & 0.0000 & 0.0002 & 0.0000 & 0.0000 & 0.0000 & 0.0003 & 0.0000 \\
\hline $\begin{array}{l}\text { manufacture and supply of } \\
\text { water. gas, electricity and } \\
\text { heat. }\end{array}$ & 0.0000 & 0.0000 & 0.0231 & 0.0000 & 0.0000 & 0.0200 & 0.0000 & 0.0000 & 0.0009 & 0.0013 & 0.0000 \\
\hline
\end{tabular}

Hunan, Zhejiang, Chongqing and Shanghai have shown a certain degree of integration between manufacturing and imported finance, but the overall level is very low. In fact, Hunan Province is relatively slightly higher in the 11 provinces of the Yangtze River Economic Belt, and the integration rate of metal smelting and imported finance is only 0.0992. For Shanghai, the integration rate of metal smelting and imported finance is 0.0204 , gas, water,electricity and heat reached 0.0200, transport equipment 0.0110 , which is slightly higher than 0.0098 in the country level. Moreover, Chongqing, as a financial center in the north of the Yangtze River Economic Belt, has a low level of integration between manufacturing and imported finance, and manufacturing and domestic finance. It indicates that Chongqing should pay more attention to the integration between 
finance and manufacturing industry. Otherwise, even though regional finance develops, its integration with manufacturing may decline. This is a phenomenon that virtual industry separates from real industry, which does harm to long-term development of economy [10]. For example, the excessive self-circulation of finance per se will increase the internal system risk, which may cause destructive impact on regional economic growth.

\subsection{A heterogeneous comparative study on the integration between domestic leasing and business services}

Leasing and business services are an indispensable part of producer services, including legal service, accounting, notarial service, consulting, advertising, design, exhibition, market management services, leasing, etc. It is knowledge-intensive, human capital-intensive, and high professional service industry, which is a catalyst for accelerating the development of manufacturing industry.

Table 9 The integration between manufacturing and domestic leasing and business services.

\begin{tabular}{|c|c|c|c|c|c|c|c|c|c|c|c|}
\hline 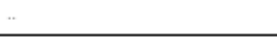 & Anhui: & Guizhou. & Hubei. & Hunan & Jiangsu.: & Jiangxi. & Shanghai.:- & Sichuan. & Yunnan. & Zhejiang, & Chongqing: \\
\hline food and tobacco products. & 0.0161 & 0.1008 & 0.0433 & 0.0011 & 0.3390 & 0.0042 & 0.0526. & 0.0648 & 0.0628 & 0.0123 & 0.0117. \\
\hline $\begin{array}{l}\text { textiles, wearing apparel } \\
\text { and leather products. }\end{array}$ & 0.0024 & 0.0000 & 0.0164 & 0.0006 & 0.0340 & 0.0013 & 0.0196 & 0.0014 & 0.0003 & 0.0061 & 0.0024 \\
\hline $\begin{array}{l}\text { wood processing products and } \\
\text { furniture. }\end{array}$ & 0.0011 & 0.0009 & 0.0005 & 0.0014 & 0.0306 & 0.0001 & 0.0021 & 0.0050 & 0.0005 & 0.0031 & 0.0003 \\
\hline $\begin{array}{l}\text { paper, printing and } \\
\text { recreational and educational } \\
\text { products. }\end{array}$ & 0.0008 & 0.0004 & 0.0046 & 0.0005 & 0.1573 & 0.0072 & 0.0057 & 0.0025 & 0.0018 & 0.0030 & $0.0008 x$ \\
\hline $\begin{array}{l}\text { coke, refined petroleum } \\
\text { products and nuclear fuel } \\
\text { processing products. }\end{array}$ & 0.0006 & 0.0003 & 0.0010 & 0.0001 & 0.0800 & 0.0040 & 0.0027 & 0.0002 & 0.0008 & 0.0004 & 0.0004 \\
\hline chemical products. & 0.0158 & 0.0320 & 0.0231 & 0.0110 & 0.0864 & 0.0151 & 0.0520 & 0.0060 & 0.0559 & 0.0293 & 0.0179 \\
\hline non-metallic mineral products. & 0.0059 & 0.0070 & 0.0055 & 0.0014 & 0.0187 & 0.0018 & 0.0038 & 0.0017 & 0.0009 & 0.0022 & 0.0030 \\
\hline $\begin{array}{l}\text { metal smelting and rolling } \\
\text { processing products. }\end{array}$ & 0.0003 & 0.0052 & 0.0030 & 0.0082 & 0.0098 & 0.0002 & 0.0114 & 0.0004 & 0.0026 & 0.0009 & 0.0057 \\
\hline metal products. & 0.0015 & 0.0003 & 0.0161 & 0.0027 & 0.0126 & 0.0037 & 0.0053 & 0.0035 & 0.0001 & 0.0039 & 0.0025. \\
\hline $\begin{array}{l}\text { general and specialized } \\
\text { equipment. }\end{array}$ & 0.0086 & 0.0037 & 0.0045 & 0.0112 & 0.0813 & 0.0069 & 0.0303 & 0.0119 & 0.0011 & 0.0089 & 0.0042 \\
\hline $\begin{array}{l}\text { instrumentation } \\
\text { communication devices. } \\
\text { computer and other electronic } \\
\text { products. }\end{array}$ & 0.0049 & 0.0112 & 0.0050 & 0.0021 & 0.2033 & 0.0000 & 0.0070. & 0.0065 & 0.0007 & 0.0059 & 0.0018 \\
\hline $\begin{array}{l}\text { electrical machinery and } \\
\text { equipment. }\end{array}$ & 0.0060 & 0.0001 & 0.0028 & 0.0019 & 0.0160 & 0.0095 & 0.0077 & 0.0084 & 0.0013 & 0.0112 & $0.0216 x$ \\
\hline transport equipment. & 0.0354 & 0.0011 & 0.0541 & 0.0055 & 0.1223 & 0.0012 & 0.0324 & 0.0096 & 0.0160 & 0.0042 & 0.0420 \\
\hline other manufactured products. & 0.0237 & 0.0004 & 0.0004 & 0.0004 & 0.0942 & 0.0000 & 0.0006 & 0.0002 & 0.0000 & 0.0016 & 0.0012 \\
\hline waste cycling. & 0.0019 & 0.0000 & 0.0000 & 0.0001 & 0.0246 & 0.0001 & 0.0005. & 0.0000 & 0.0000 & 0.0000 & 0.0000. \\
\hline $\begin{array}{l}\text { manufacture and supply of } \\
\text { water. gas, electricity and } \\
\text { heat. }\end{array}$ & 0.0012 & 0.0007 & 0.0023 & 0.0120 & 0.0007 & 0.0013 & 0.0015 & 0.0027 & 0.0000 & 0.0020 & 0.0026 \\
\hline
\end{tabular}

Jiangsu Province has a higher integration level in 11 provinces. Specifically, food and tobacco has the highest integration rate of 0.3390 . At the same time, the integration rate of paper , printing and cultural and educational goods and domestic leasing and business services reached 0.1573 and its instrumentation、communication devices computer and other electronic devices is 0.2032. Moreover, textile、 wearing apparel and leather products, wood processing products and furniture, coke、 petroleum products and nuclear fuel processing products, chemical products, non-metallic 
mineral products, transport equipment, other manufactured products, waste recycling all rank first in the 11 provinces of the Yangtze River Economic Belt.

This result shows that the overall integration between manufacturing and domestic leasing and business services in Jiangsu is better than that of other ones in 11 provinces. It is found that Jiangsu is a famous manufacturing province of China. Its manufacturing is large-scale, and has good foundation, and its emerging industries are growing fast, and industrial structure is continuously optimized. Especially the integration between manufacturing and producer services is relatively better than Zhejiang and Shanghai in the Yangtze River Economic Belt downstream area, as well as better than other provinces in the midstream and upstream area. In 2015, Jiangsu's economic output was second only to Guangdong, ranking 2th in China. Especially, the domestic producer services effectively promote the development of Jiangsu's manufacturing industry, helping cultivate local industrial chain. And this creates a good development environment for local brands to emerge and grow in the future. Moreover, the situation in Shanghai and Zhejiang is slightly worse than Jiangsu and the integration level of manufacturing and domestic leasing and business services in the midand upstream Yangtze River, such as Guizhou and Jiangxi, is relatively low. It shows that domestic professional services have not been adopted well into the manufacturing in relatively underdeveloped provinces mainly located in the Yangtze River mid- and upstream area.

Table 10 The integration between manufacturing and imported leasing and business services.

\begin{tabular}{|c|c|c|c|c|c|c|c|c|c|c|c|}
\hline$\cdots$ & Anhui. & Guizhour. & Hubei.: & Hunan: & Jiangsu. & Jiangxi & Shanghai & Sichuan. & Yunnan. & Zhejiang & Chongqin \\
\hline food and tobacco products. & 0.0000 & 0.0000 & 0.0162 & 0.1035 & 0.0000 & 0.0553 & 0.0000 & 0.0000 & 0.0482 & 0.1025 & 0.0000 \\
\hline $\begin{array}{l}\text { textiles. wearing apparel } \\
\text { and leather products. }\end{array}$ & 0.0000 & 0.0000 & 0.0078 & 0.1284 & 0.0000 & 0.0290 & 0.0000 & 0.0000 & 0.0330 & 0.0281 & 0.0000 \\
\hline $\begin{array}{l}\text { wood processing products and } \\
\text { fumiture. }\end{array}$ & 0.0000 & 0.0000 & 0.0145 & 0.0209 & 0.0000 & 0.0024 & 0.0000 & 0.0000 & 0.0149 & 0.0039 & 0.0000 \\
\hline $\begin{array}{l}\text { paper. printing and } \\
\text { recreational and educational } \\
\text { products.s }\end{array}$ & 0.0000 & 0.0000 & 0.0049 & 0.0392 & 0.0000 & 0.0062 & 0.0000 & 0.0000 & 0.0172 & 0.0141 & 0.0000 \\
\hline $\begin{array}{l}\text { coke, refined petroleum } \\
\text { products and nuclear fuel } \\
\text { processing products. }\end{array}$ & 0.0000 & 0.0000 & 0.0029 & 0.0042 & 0.0000 & 0.0023 & 0.0000 & 0.0000 & 0.0016 & 0.0043 & 0.0000 \\
\hline chemical products. & 0.0000 & 0.0000 & 0.0947 & 0.2051 & 0.0000 & 0.0509 & 0.0000 & 0.0000 & 0.1377 & 0.1217 & 0.0000 \\
\hline non-metallic mineral products. & 0.0000 & 0.0000 & 0.0124 & 0.0163 & 0.0000 & 0.0039 & 0.0000 & 0.0000 & 0.0126 & 0.0353 & 0.0000 \\
\hline $\begin{array}{l}\text { metal smelting and rolling } \\
\text { processing products. }\end{array}$ & 0.0000 & 0.0000 & 0.0716 & 0.0196 & 0.0000 & 0.0100 & 0.0000 & 0.0000 & 0.0070 & 0.0604 & 0.0000 \\
\hline metal products.s & 0.0000 & 0.0000 & 0.0229 & 0.0267 & 0.0000 & 0.0053 & 0.0000 & 0.0000 & 0.0225 & 0.0172 & 0.0000 \\
\hline $\begin{array}{l}\text { general and specialized } \\
\text { equipment. }\end{array}$ & 0.0000 & 0.0000 & 0.1037 & 0.0997 & 0.0000 & 0.0301 & 0.0000 & 0.0000 & 0.0507 & 0.0422 & 0.0000 \\
\hline $\begin{array}{l}\text { instrumentation } \\
\text { communication devices. } \\
\text { computer and other electronic } \\
\text { products. }\end{array}$ & 0.0000 & 0.0000 & 0.0241 & 0.1624 & 0.0000 & 0.0116 & 0.0000 & 0.0000 & 0.0260 & 0.0419 & 0.0000 \\
\hline $\begin{array}{l}\text { electrical machinery and } \\
\text { equipment. }\end{array}$ & 0.0000 & 0.0000 & 0.0180 & 0.0483 & 0.0000 & 0.0099 & 0.0000 & 0.0000 & 0.0510 & 0.0949 & 0.0000 \\
\hline transport equipment. & 0.0000 & 0.0000 & 0.0472 & 0.1127 & 0.0000 & 0.0475 & 0.0000 & 0.0000 & 0.0236 & 0.3450 & 0.0000 \\
\hline other manufactured products. & 0.0000 & 0.0000 & 0.0034 & 0.0019 & 0.0000 & 0.0006 & 0.0000 & 0.0000 & 0.0065 & 0.0091 & 0.0000 \\
\hline waste cycling. & 0.0000 & 0.0000 & 0.0006 & 0.0020 & 0.0000 & 0.0003 & 0.0000 & 0.0000 & 0.0002 & 0.0001 & 0.0000 \\
\hline $\begin{array}{l}\text { manufacture and supply of } \\
\text { water. gas. electricity and } \\
\text { heat.s }\end{array}$ & 0.0000 & 0.0000 & 0.0823 & 0.0086 & 0.0000 & 0.0011 & 0.0000 & 0.0000 & 0.0167 & 0.0247 & 0.0000 \\
\hline
\end{tabular}

Only Hunan, Zhejiang, Chongqing, Jiangsu and Shanghai import leasing and business services in the 11 provinces in the Yangtze River Economic Belt. Specifically, the integration between food and tobacco industry and imported leasing and business services is relatively high in Chongqing and Jiangsu, reaching 0.1025 and 0.1035 respectively. At the same time, only considering the 
integration with imported leasing and business services, the integration rates of textile, wearing apparel and leather products, chemical products, instrumentation, communication devices, computers and other electronic equipment as well as transport equipment reached $0.1284,0.2051$, 0.1624 and 0.1127 respectively in Jiangsu. Chongqing's food and tobacco, chemical products and transport equipment are $0.1025,0.1217$ and 0.3450 respectively. Finally, the integration level of general and specialized equipment and imported leasing and business services in Hunan is 0.1037. Generally speaking, those highlight the deep integration of manufacturing with regional characteristics and imported leasing and business services in Jiangsu, Chongqing and Hunan.

The Shanghai Free Trade Zone was established in September 2014. Then the Fujian, Tianjin and Guangdong Free Trade Zone were created afterwards, those mean the gradual expansion of China's service liberalization. However, the integration rate of manufacturing and imported leasing and business services in Shanghai is relatively small, all manufacturing sub-industries less than 0.02. This indicates that Shanghai still remains breadth integration, but has not yet possessed deep integration advantages. So government should adhere to the gradual opening up policy for services, from the coastal area to the mainland and promote fair competition of different ownership firms, and adopt incentive measures to encourage manufacturing to input more producer services and at the same time, introduce more producer services to manufacturing. Finally, this will facilitate their integration.

\subsection{A heterogeneous comparative study on the integration between manufacturing and Computer software and information services}

Computer software and information services industry includes telecommunications 、 broadcast, television, satellite transmission services, internet and related services. In the age of information, service industry has become increasingly prominent. The effective mutual penetration between manufacturing and information services is critical to industrial upgrade.

Table 11 The integration between manufacturing and domestic computer software and information service.

\begin{tabular}{|c|c|c|c|c|c|c|c|c|c|c|c|}
\hline$\ldots$ & Anhui. & Guizhou & Hubei. & Hunan. & Jiangau. & Jiangxi. & Shanghai . & Sichuan. & Yunnen. & Zhejiang & Chongqing. \\
\hline food and tobacco products. & 0.0004 & 0.0083 & 0.0017 & 0.0016 & 0.0001 & 0.0018 & 0.0006 & 0.0194 & 0.0009 & 0.0022 & 0.0008 \\
\hline $\begin{array}{l}\text { textiles, wearing apparel } \\
\text { and leather products. }\end{array}$ & 0.0007 & 0.0000 & 0.0034 & 0.0042 & 0.0266 & 0.0023 & 0.0166 & 0.0059 & 0.0000 & 0.0225 & 0.0020 . \\
\hline $\begin{array}{l}\text { wood processing products and } \\
\text { furniture. }\end{array}$ & 0.0007 & 0.0003 & 0.0001 & 0.0008 & 0.0001 & 0.0002 & 0.0004 & 0.0014 & 0.0001 & 0.0033 & 0.0003 \\
\hline $\begin{array}{l}\text { paper, printing and } \\
\text { recreational and educational } \\
\text { products. }\end{array}$ & 0.0008 & 0.0000 & 0.0019 & 0.0003 & 0.0003 & 0.0010 & 0.0031 & 0.0022 & 0.0002 & 0.0051 & $0.0002=$ \\
\hline $\begin{array}{l}\text { coke, refined petroleum } \\
\text { products and nuclear fuel } \\
\text { processing products. }\end{array}$ & 0.0000 & 0.0000 & 0.0000 & 0.0000 & 0.0002 & 0.0000 & 0.0000 & 0.0014 & 0.0001 & 0.0000 & $0.0007=$ \\
\hline chemical products. & 0.0007 & 0.0102 & 0.0018 & 0.0159 & 0.0001 & 0.0051 & 0.0047 & 0.0055 & 0.0022 & 0.0054 & 0.0072 \\
\hline non-metallic mineral products. & 0.0001 & 0.0012 & 0.0016 & 0.0031 & 0.0001 & 0.0130 & 0.0003 & 0.0034 & 0.0002 & 0.0013 & 0.0006 \\
\hline $\begin{array}{l}\text { metal smelting and rolling } \\
\text { processing products. }\end{array}$ & 0.0002 & 0.0011 & 0.0001 & 0.0006 & 0.0022 & 0.0011 & 0.0001 & 0.0146 & 0.1092 & 0.0017 & 0.0113. \\
\hline metal products. & 0.0002 & 0.0001 & 0.0030 & 0.0013 & 0.0001 & 0.0014 & 0.0053 & 0.0003 & 0.0001 & 0.0068 & 0.0000 \\
\hline $\begin{array}{l}\text { general and specialized } \\
\text { equipment. }\end{array}$ & 0.0006 & 0.0002 & 0.0010 & 0.0039 & 0.0003 & 0.0029 & 0.0108 & 0.0018 & 0.0002 & 0.0279 & 0.0107. \\
\hline $\begin{array}{l}\text { instrumentation } \\
\text { communication devices. } \\
\text { computer and other electronic } \\
\text { products. }\end{array}$ & 0.0029 & 0.0001 & 0.0002 & 0.0012 & 0.0004 & 0.0001 & 0.0150 & 0.0059 & 0.0003 & 0.0043 & 0.0075. \\
\hline $\begin{array}{l}\text { electrical machinery and } \\
\text { equipment. }\end{array}$ & 0.0023 & 0.0001 & 0.0004 & 0.0008 & 0.0007 & 0.0006 & 0.0198 & 0.0008 & 0.0000 & 0.0026 & 0.0033 \\
\hline transport equipment . & 0.0002 & 0.0000 & 0.0009 & 0.0002 & 0.0001 & 0.0002 & 0.0010 & 0.0052 & 0.0001 & 0.0028 & 0.0068 \\
\hline other manufactured products. & 0.0000 & 0.0000 & 0.0002 & 0.0004 & 0.0015 & 0.0000 & 0.0044 & 0.0000 & 0.0000 & 0.0014 & 0.0000 \\
\hline waste cycling. & 0.0000 & 0.0002 & 0.0002 & 0.0000 & 0.0032 & 0.0008 & 0.0001 & 0.0000 & 0.0000 & 0.0001 & 0.0000 \\
\hline $\begin{array}{l}\text { manufacture and supply of } \\
\text { water. gas、 electricity and } \\
\text { heat. }\end{array}$ & 0.0001 & 0.0045 & 0.0020 & 0.0006 & 0.0004 & 0.0009 & $0.0247=$ & 0.0053 & 0.0035 & 0.0025 & 0.0001. \\
\hline
\end{tabular}


At present, the overall integration level of manufacturing and domestic computer software and information services is low in the Yangtze River Economic Belt, indicating that there is still a lot of work to be done in promoting further integration.

Among the 11 provinces in the Yangtze River Economic Belt, Zhejiang's manufacturing has a relatively high integration level with domestic computer software and information services, including wood processing products and furniture, paper、printing and cultural and educational goods, metal products, and general and specialized equipment. They are 0.0033, 0.0050, 0.0068 and 0.0278 respectively, ranking first among the 11 provinces in the Yangtze River Economic Belt. At the same time, for Shanghai, the integration rate with domestic computer software and information services is 0.0150 for instrumentation、 communication devices computers and other electronic equipment, 0.0198 for electrical machinery and equipment, and 0.0043 for gas, water, electricity and heat. It is can be seen that although Shanghai is the one with the highest integration level in the 11 provinces of the Yangtze River Economic Belt, but its level is still very low. This means that even the Yangtze River Economic Belt, China's largest economic belt, has not yet achieved a good integration between manufacturing and domestic information services.

But if the manufacturing and information service industry cannot be effectively integrated, there will be a lag effect on intelligent manufacturing, industrial up grade, and even China Manufacturing 2025. Although relevant departments have exerted themselves on this, informatization of manufacturing is still too low to meet the requirement of manufacturing upgrade.

Moreover, for Sichuan, the integration rate between food and tobacco industry and domestic information services reached 0.0193 , and that between coke, petroleum products and nuclear fuel processing products and domestic information services is 0.0013 . Those are the highest integration rates among the 11 provinces in the Yangtze River Economic Belt. However, in fact, those rates are still a low level. Therefore, accelerating the integration between manufacturing and domestic information services is one of the key tasks for the Yangtze River Economic Belt later. Local governments and firms must adjust to local conditions and adopt unique and integrated measures based on their characteristics to promote the development of their advantageous manufacturing. 
Table 12 The integration between manufacturing and imported computer software and information services.

The integration rate between manufacturing and imported computer software and information. services in 11 provinces of the Yangtze River Economic Belt.

\begin{tabular}{|c|c|c|c|c|c|c|c|c|c|c|c|}
\hline 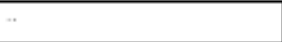 & Anhui. & Guizhon, & Hubei. & Human & Jiangsu. & Jiangri. & Shanghail & Sichum, & Yuman. & Zhejiang & Chougging: \\
\hline food and tobacco products. & 0.0000 & 0.0000 & 0.0012 & 0.0000 & 0.0000 & 0.0005 & 0.0000 & 0.0000 & 0.0001 & 0.0001 & 0.0000 \\
\hline $\begin{array}{l}\text { textiles, wearing apparel } \\
\text { and leather prochucts. }\end{array}$ & 0.0000 & 0.0000 & 0.0027 & 0.0000 & 0.0000 & 0.0197 & 0.0000 & 0.0000 & 0.0014 & 0.0004 & 0.0000 \\
\hline $\begin{array}{l}\text { wood processing procucts and } \\
\text { fumiture. }\end{array}$ & 0.0000 & 0.0000 & 0.0005 & 0.0000 & 0.0000 & 0.0004 & 0.0000 & 0.0000 & 0.0002 & 0.0001 & 0.0000 \\
\hline $\begin{array}{l}\text { paper, printing and } \\
\text { recreational and educational } \\
\text { products. }\end{array}$ & 0.0000 & 0.0000 & 0.0002 & 0.0000 & 0.0000 & 0.0027 & 0.0000 & 0.0000 & 0.0003 & 0.0001 & 0.0000 \\
\hline $\begin{array}{l}\text { coke, refined petroleum } \\
\text { products and nuclear fuel } \\
\text { processing products. }\end{array}$ & 0.0000 & 0.0000 & 0.0000 & 0.0000 & 0.0000 & 0.0000 & 0.0000 & 0.0000 & 0.0000 & 0.0001 & 0.0000 \\
\hline chemical products. & 0.0000 & 0.0000 & 0.0073 & 0.0000 & 0.0001 & 0.0036 & 0.0000 & 0.0000 & 0.0003 & 0.0008 & 0.0000. \\
\hline non-metallic mineral products. & 0.0000 & 0.0000 & 0.0015 & 0.0000 & 0.0004 & 0.0003 & 0.0000 & 0.0000 & 0.0001 & 0.0001 & 0.0000 \\
\hline $\begin{array}{l}\text { metal smelting and rolling } \\
\text { processing products. }\end{array}$ & 0.0000 & 0.0000 & 0.0003 & 0.0000 & 0.0000 & 0.0001 & 0.0000 & 0.0000 & 0.0002 & 0.0020 & 0.0000 \\
\hline metal products. & 0.0000 & 0.0000 & 0.0006 & 0.0000 & 0.0001 & 0.0042 & 0.0000 & 0.0000 & 0.0005 & 0.0000 & 0.0000 \\
\hline $\begin{array}{l}\text { general and specialized } \\
\text { equipment. }\end{array}$ & 0.0000 & 0.0000 & 0.0019 & 0.0000 & 0.0001 & 0.0086 & 0.0000 & 0.0000 & 0.0019 & 0.0018 & 0.0000 \\
\hline $\begin{array}{l}\text { instrumentation } \\
\text { communication devices, } \\
\text { computer and other electronic } \\
\text { products. }\end{array}$ & 0.0000 & 0.0000 & 0.0003 & 0.0000 & 0.0000 & 0.0200 & 0.0000 & 0.0000 & 0.0002 & 0.0030 & 0.0000 \\
\hline $\begin{array}{l}\text { electrical machinery and } \\
\text { equipment. }\end{array}$ & 0.0000 & 0.0000 & 0.0004 & 0.0000 & 0.0000 & 0.0204 & 0.0000 & 0.0000 & 0.0001 & 0.0002 & 0.0000 \\
\hline transport equipment. & 0.0000 & 0.0000 & 0.0001 & 0.0000 & 0.0000 & 0.0012 & 0.0000 & 0.0000 & 0.0002 & 0.0009 & 0.0000 \\
\hline other manufactured products. & 0.0000 & 0.0000 & 0.0002 & 0.0000 & 0.0000 & 0.0038 & 0.0000 & 0.0000 & 0.0001 & 0.0000 & 0.0000 \\
\hline waste cycling, & 0.0000 & 0.0000 & 0.0000 & 0.0000 & 0.0000 & 0.0000 & 0.0000 & 0.0000 & 0.0000 & 0.0000 & 0.0000 \\
\hline $\begin{array}{l}\text { manufacture and surply of } \\
\text { water. gas, electricity and } \\
\text { heat. }\end{array}$ & 0.0000 & 0.0000 & 0.0002 & 0.0000 & 0.0000 & 0.0140 & 0.0000 & 0.0000 & 0.0002 & 0.0000 & 0.0000. \\
\hline
\end{tabular}

There is a certain degree of integration between imported computer software and information services and manufacturing in Hunan, Zhejiang, Chongqing and Shanghai in the Yangtze River Economic Belt. But they are in a low level, all below 0.1. Other provinces have not yet imported information services. Specifically, Shanghai is less than 0.03, Hunan, Chongqing and Zhejiang are at a lower level than Shanghai. That is to say, the positive effect of information services on the development of manufacturing has not been fully exerted. In the era of Internet + , we must make great efforts to accelerate the integration between information technology and manufacturing. Because this is crucial for the smooth implementation of China Manufacturing 2025. 


\subsection{A heterogeneous comparative study on the integration between manufacturing and scientific research and technological services}

Table 13The integration between manufacturing and domestic scientific research and technological services.

\begin{tabular}{|c|c|c|c|c|c|c|c|c|c|c|c|}
\hline 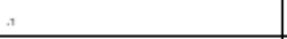 & Anhui & Guizhou. & Hubei & Hunan & Jiangsu: & Jiangxi & Shanghai. & Sichuan. & Yunnan. & Zhejiang. & Chongqins \\
\hline food and tobacco products. & 0.0003 & 0.0187 & 0.0001 & 0.0002 & 0.0001 & 0.0040 & 0.0022 & 0.0082 & 0.0128 & 0.0001 & 0.0000 \\
\hline $\begin{array}{l}\text { textiles, wearing apparel } \\
\text { and leather products. }\end{array}$ & 0.0004 & 0.0000 & 0.0004 & 0.0001 & 0.0000 & 0.0002 & 0.0002. & 0.0006 & 0.0000 & 0.0006 & 0.0000 \\
\hline $\begin{array}{l}\text { wood processing products and } \\
\text { furniture. }\end{array}$ & 0.0003 & 0.0000 & 0.0001 & 0.0004 & 0.0013 & 0.0001 & 0.0000 & 0.0004 & 0.0001 & 0.0005 & 0.0000 \\
\hline $\begin{array}{l}\text { paper. printing and } \\
\text { recreational and educational } \\
\text { products. }\end{array}$ & 0.0002 & 0.0000 & 0.0000 & 0.0001 & 0.0001 & 0.0025 & 0.0002 & 0.0004 & 0.0005 & 0.0004 & 0.0000 \\
\hline $\begin{array}{l}\text { coke, refined petroleum } \\
\text { products and nuclear fuel } \\
\text { processing products. }\end{array}$ & 0.0000 & 0.0000 & 0.0000 & 0.0003 & 0.0000 & 0.0001 & 0.0000 & 0.0004 & 0.0001 & 0.0000 & 0.0000 \\
\hline chemical products. & 0.0061 & 0.0015 & 0.0029 & 0.0081 & 0.0000 & 0.0019 & 0.0023 & 0.0155 & 0.0094 & 0.0079 & 0.0006 \\
\hline non-metallic mineral products. & 0.0000 & 0.0000 & 0.0012 & 0.0002 & 0.0002 & 0.0082 & 0.0000 & 0.0022 & 0.0007 & 0.0001 & 0.0000 \\
\hline $\begin{array}{l}\text { metal smelting and rolling } \\
\text { processing products. }\end{array}$ & 0.0003 & 0.0000 & 0.0000 & 0.0017 & 0.0001 & 0.0006 & 0.0003 & 0.0002 & 0.0057 & 0.0003 & 0.0000 \\
\hline metal products. & 0.0005 & 0.0000 & 0.0004 & 0.0017 & 0.0000 & 0.0058 & 0.0003 & 0.0003 & 0.0004 & 0.0048 & 0.0000 \\
\hline $\begin{array}{l}\text { general and specialized } \\
\text { equipment. }\end{array}$ & 0.0012 & 0.0000 & 0.0007 & 0.0011 & 0.0053 & 0.0096 & 0.0032 & 0.0147 & 0.0023 & 0.0090 & 0.0030 \\
\hline $\begin{array}{l}\text { instrumentation } \\
\text { communication devices. } \\
\text { computer and other electronic } \\
\text { products. }\end{array}$ & 0.0009 & 0.0124 & 0.0006 & 0.0008 & 0.0015 & 0.0001 & 0.0005 & 0.0006 & 0.0025 & 0.0012 & 0.0016 \\
\hline $\begin{array}{l}\text { electrical machinery and } \\
\text { equipment. }\end{array}$ & 0.0012 & 0.0000 & 0.0024 & 0.0004 & 0.0063 & 0.0001 & 0.0020 & 0.0011 & 0.0007 & 0.0062 & 0.0001 \\
\hline transport equipment. & 0.0029 & 0.0057 & 0.0113 & 0.0053 & 0.0004 & 0.0036 & 0.0272 & 0.0129 & 0.0113 & 0.0029 & 0.0462 \\
\hline other manufactured products. & 0.0000 & 0.0000 & 0.0010 & 0.0000 & 0.0002 & 0.0000 & 0.0004 & 0.0000 & 0.0001 & 0.0002 & 0.0000 \\
\hline waste cycling.: & 0.0000 & 0.0000 & 0.0000 & 0.0000 & 0.0000 & 0.0000 & 0.0000 & 0.0000 & 0.0000 & 0.0000 & 0.0000 \\
\hline $\begin{array}{l}\text { manufacture and supply of } \\
\text { water. gas, electricity and } \\
\text { heat. }\end{array}$ & 0.0000 & 0.0000 & 0.0003 & 0.0001 & 0.0001 & 0.0000 & 0.0000 & 0.0002 & 0.0108 & 0.0004 & 0.0000 \\
\hline
\end{tabular}

As a basic industry for manufacturing innovation, the production of new products requires the support of scientific research and technological services, which is definitely ind ispensable for the manufacturing chain of the Yangtze River Economic Belt. It is a fundamental way for a firm to maintain strong and sustainable competitiveness. It is can be seen from above table that the integration of manufacturing and domestic scientific research and technological services is in a low level in the Yangtze River Economic Belt.

Although, Shanghai is a national leader in reform and opening up, its integration between manufacturing and domestic scientific research and technological services has no obvious edge in the 11 provinces of the Yangtze River Economic Belt. This indicates that even in the Yangtze River Economic Belt, its manufacturing upgrade has not yet succeeded, and it is just in the course of reform. Zhejiang's textile, wearing apparel and leather products industry is better integrated with domestic scientific research and technology services, ranking first among the 11 provinces, but the integration rate is only 0.0006 . At the same time, Jiangsu's wood processing products and furniture, as well as electrical machinery and equipment are integrated well with domestic scientific research and technology services, the integration rates are 0.0013 and 0.0063 respectively, which are still low. 
As a global center of science and technology innovation under construction, the integration rate between transport equipment represented by Shanghai Automotive Industry Corporation(SAIC)and domestic scientific research and technological services reached the second place in the 11 provinces of the Yangtze River Economic Belt, slightly lower than Chongqing 0.0271. Considering the integration with domestic scientific research and technology services, Jiangxi's paper、printing and cultural and educational goods, non-metallic mineral products are 0.0024 and 0.0057 respectively in the midstream area of Yangtze River Economic Belt, and Guizhou has an edge in food and beverage, instrumentation, communication devices, computers and other electronic equipment. In general, compared with the relatively developed provinces in Yangtze River Delta and the relatively underdeveloped ones in the mid-and upstream area of Yangtze River Economic Belt, there is no significant advantage for the former in integration.

The results sounded an alarm to us. It is concluded that there is still a gap between the Yangtze River Economic Belt and developed countries and regions in producer services development. However, if we further look at the integration level of manufacturing and producer services, the situation is even less optimistic. Because the integration of real economy and virtual economy is far from ideal. In other words, taking the Yangtze River delta as an example, although its manufacturing and producer services all have been making great progress, such as the establishment of financial centers, trade centers, and shipping centers, etc., the interaction between them is not good. It only shows integration breadth, but there is no advantage of deep integration. We believe that industrial clusters represented by Shanghai have shown signs of separation between producer services and manufacturing. In this case, we need to take measures to make producer services an effective catalyst for promoting the development of the manufacturing industry.

Table 14 The integration between manufacturing and imported scientific research and technological services

\begin{tabular}{|c|c|c|c|c|c|c|c|c|c|c|c|}
\hline 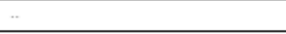 & Anhui. & Guizhou. & Hubei.. & Hunan. & Jiangsu. & Jiangxi. & Shanghai. & Sichuan. & Yunnan. & Zhejiang. & Chongqing. \\
\hline food and tobacco products. & 0.0699 & 0.0000 & 0.0001 & 0.0000 & 0.0000 & 0.0028 & 0.1888 & 0.0000 & 0.0000 & 0.0000 & 0.0699 \\
\hline $\begin{array}{l}\text { textiles, wearing apparel } \\
\text { and leather products. }\end{array}$ & 0.0541 & 0.0000 & 0.0001 & 0.0000 & 0.0000 & 0.0004 & 0.0245 & 0.0000 & 0.0000 & 0.0000 & 0.0541 \\
\hline $\begin{array}{l}\text { wood processing products and } \\
\text { furniture. }\end{array}$ & 0.0252 & 0.0000 & 0.0002 & 0.0000 & 0.0000 & 0.0000 & 0.0159 & 0.0000 & 0.0000 & 0.0000 & 0.0252 \\
\hline $\begin{array}{l}\text { paper, printing and } \\
\text { recreational and educational } \\
\text { products. }\end{array}$ & 0.0193 & 0.0000 & 0.0000 & 0.0000 & 0.0000 & 0.0002 & 0.0173 & 0.0000 & 0.0000 & 0.0000 & $0.0193=$ \\
\hline $\begin{array}{l}\text { coke, refined petroleum } \\
\text { products and nuclear fuel } \\
\text { processing products. }\end{array}$ & 0.0004 & 0.0000 & 0.0004 & 0.0000 & 0.0000 & 0.0000 & 0.0110 & 0.0000 & 0.0000 & 0.0000 & 0.0004 \\
\hline chemical products. & 0.2805 & 0.0000 & 0.0030 & 0.0000 & 0.0000 & 0.0027 & 0.2370 & 0.0000 & 0.0000 & 0.0000 & 0.2805 \\
\hline non-metallic mineral products. & 0.0054 & 0.0000 & 0.0001 & 0.0000 & 0.0000 & 0.0000 & 0.0678 & 0.0000 & 0.0000 & 0.0000 & 0.0054 \\
\hline $\begin{array}{l}\text { metal amelting and rolling } \\
\text { processing products. }\end{array}$ & 0.0595 & 0.0000 & 0.0007 & 0.0000 & 0.0000 & 0.0003 & 0.0211 & 0.0000 & 0.0000 & 0.0000 & 0.0595 \\
\hline metal products.. & 0.0395 & 0.0000 & 0.0006 & 0.0000 & 0.0000 & 0.0004 & 0.0145 & 0.0000 & 0.0000 & 0.0000 & 0.0395 \\
\hline $\begin{array}{l}\text { general and specialized } \\
\text { equipment. }\end{array}$ & 0.1074 & 0.0000 & 0.0005 & 0.0003 & 0.0000 & 0.0038 & 0.1744 & 0.0000 & 0.0000 & 0.0000 & 0.1074 \\
\hline $\begin{array}{l}\text { instrumentation } \\
\text { communication devices. } \\
\text { computer and other electronic } \\
\text { products. }\end{array}$ & 0.0593 & 0.0000 & 0.0004 & 0.0000 & 0.0000 & 0.0010 & 0.0390 & 0.0000 & 0.0000 & 0.0000 & 0.0593 \\
\hline $\begin{array}{l}\text { electrical machinery and } \\
\text { equipment. }\end{array}$ & 0.1141 & 0.0000 & 0.0001 & 0.0008 & 0.0000 & 0.0031 & 0.0302 & 0.0000 & 0.0000 & 0.0000 & $0.1141=$ \\
\hline transport equipment. & 0.1637 & 0.0000 & 0.0019 & 0.0000 & 0.0000 & 0.0483 & 0.1356 & 0.0000 & 0.0000 & 0.0000 & 0.1637 \\
\hline other manufactured products. & 0.0007 & 0.0000 & 0.0000 & 0.0000 & 0.0000 & 0.0006 & 0.0008 & 0.0000 & 0.0000 & 0.0000 & 0.0007 \\
\hline waste cycling & 0.0000 & 0.0000 & 0.0000 & 0.0000 & 0.0000 & 0.0000 & 0.0000 & 0.0000 & 0.0000 & 0.0000 & $0.0000=$ \\
\hline $\begin{array}{l}\text { manufacture and supply of } \\
\text { water. gas. electricity and } \\
\text { heat.s }\end{array}$ & 0.0011 & 0.0000 & 0.0000 & 0.0000 & 0.0000 & 0.0000 & 0.0221 & 0.0000 & 0.0000 & 0.0000 & 0.0011 \\
\hline
\end{tabular}


Only Anhui, Sichuan and Shanghai have imported scientific research and technological services. Just considering the integration with imported scientific research and technology services, the integration rates of food and tobacco, paper and printing, chemical products, general and specialized equipment and transport equipment in Sichuan were relatively high, they are 0.1888, 0.23700 .1744 and 0.1356 respectively. And chemical products, general and specialized equipment, electrical machinery and equipment and transport equipment in Anhui reached 0.2805, 0.1074, 0.1141 and 0.1637 respectively. In contrast, although Shanghai also imports scientific research and technological services, the integration rate with manufacturing has not exceeded 0.05 . While Jiangsu, Zhejiang, Hunan, Jiangxi, Yunnan, Chongqing have not imported scientific research and technological services. Even though Jiangsu and Zhejiang belong to the downstream area of the Yangtze River Economic Belt with higher liberalization level, in 2012, the import volume of scientific research and technological services remained zero.

Therefore, China's service industry needs further opening up, especially for scientific research and technological services which are beneficial for china's technological innovation and development, government can strength international collaboration in country level, actively introducing advanced technologies from developed countries. This is considerably constructive to the Yangtze River Economic Belt, even the whole country.

In conclusion, the opening level of producer services in the whole Yangtze River Economic Belt is relatively low, reflected in that not all provinces import producer services, including wholesale and retail, transport, warehousing and postal services, finance, leasing and business services, computer software and information services and scientific research and technological services. Moreover, Shanghai, as one of the developed coastal cities in China, has imple mented a good service introduction policy earlier. For example, the establishment of Shanghai Free Trade Zone is one of the reflections to liberalize service industry. However, from the results of this paper, although Shanghai's domestic producer services are relatively developed and imported producer services have an advantage in breadth, there is no edge in deep integration for both domestic and imported producer services. Producer services as a catalyst of industrial upgrade and a core link of ind ustrial chain (Chris tof Parnreiter, 2014) must be rooted in manufacturing industry to achieve the integration between them. Therefore, for the Yangtze River Economic Belt, there is a long way to go.

\section{Conclusions}

The Yangtze River Economic Belt, as the largest regional economic belt occupying two fifths of China 's total economic output, is a national strategic region. Based on the important position of the Yangtze River Economic Belt, this paper uses input-output method to study its integration between manufacturing servitization and service manufacturization and takes use of non-competitive input-output model to subdivide producer services into domestic producer services and imported producer services, then measures the integration rates of manufacturing and domestic producer services, and manufacturing and imported producer services.

There is no obvious advantage for the downstream area of Yangtze River Economic Belt in the integration between manufacturing and producer services.

The Yangtze River Delta, represented by Shanghai, Jiangsu and Zhejiang in the downstream area of Yangtze River Economic Belt, is a relatively developed region of China. Shanghai's producer services are relatively developed and its med-and high-tech producer services have an advantage of the breadth integration with manufacturing. While manufacturing industries with regional 
characteristics and equipment manufacturing are relatively developed in Jiangsu and Zhejiang, they have an advantage of the depth integration with producer services. This indicates that on the one hand, the more developed the regional producer services, the more diverse integration of low-, mid-, and high-tech producer services and manufacturing. On the other hand, we found that although the downstream area of Yangtze River Economic Belt has an edge in producer services, its integration with manufacturing is not satisfying, such as Shanghai's breadth integration rather than depth integration. It is believed that the downstream area of Yangtze River area is dedicated to OEM processing, this helps realize ind ustrial transfer, which started from Jiangsu, Zhejiang and Shanghai, but the existing local manufacturing firms have not formed self-own brands, and built complete local industrial chains. Therefore, manufacturing's demand for domestic and imported producer services is small, almost unlikely to obtain the integration advantages.

One the one hand, the opening up of downstream provinces of the Yangtze River Economic Belt is slightly earlier than the midstream and upstream ones in the Yangtze River Economic Belt.

Compared with the mid- and upstream provinces of the Yangtze River Economic Belt, Shanghai, Zhejiang and Jiangsu in downstream area of Yangtze River Economic Belt have imported more producer services overseas. In particular, Shanghai imports a wide range of producer services, such as wholesale and retail, transport、warehousing and postal services, finance, leasing and business services, computer software and information services, scientific research and technological services. Zhejiang is the case too, except that it has not yet imported scientific research and technological services and Jiangsu has less opening up level than Shanghai and Zhejiang. However, if we further look at the integration rate of imported producer services and manufacturing, Shanghai's overall level is still low. In fact, Jiangsu's performance is better than that in Shanghai and Zhejiang.

Therefore, even though the downstream provinces of the Yangtze River Economic Belt have already been in the process of gradual opening up, imported producer services have not yet achieved a dynamic integration with manufacturing industry. In the next step, on the basis of Free Trade Zones in Shanghai, Fujian, Guangdong and Tianjin, the opening up of service industry will be further expanded.

One the other hand, accelerating the integration between producer services and manufacturing and increasing the integration rates between them is the core of industrial upgrade for the Yangtze River Economic Belt.

Although there is certain degree of integration between producer services and manufacturing, the overall level is low. Even the Shanghai, Zhejiang and Jiangsu in the downstream Yangtze River Economic Belt with higher degree of openness have not realized good integration. The reason may be that Yangtze River Delta has not yet been able to accomplish the transformation from processing manufacturing to self-own brands manufacturing. Specifically, manufacturing 's demand for producer services is insufficient. On the other hand, the finance centers, Shanghai and Chongqing, whose developing is relatively fast, have also not yet achieved a good integration with local manufacturing industries. Therefore, the good integration between manufacturing and producer services not only contributes to the development of manufacturing, but also vital to the healthy growth of producer services. Excessive self-circulation of service industry per se is destructive to ind ustrial upgrade. In the long run, real industry and virtual industry will be separated from each other, which increases systemic risks and endangers entire economy. The US financial crisis was a lesson[12].

Therefore, we believe that it is imperative to develop and cultivate local manufacturing brands as soon as possible in the Yangtze River Economic Belt, but this must base on advantageous ind ustries 
and avoid rushing into outdated models. This will bring a demonstration effect for industrial upgrade to other regions in China.

\section{Acknowledgment}

This research was financially supported by:

2017 Shanghai Social Science Planning General Research Projects: Producer service liberalization effects China manufacturing upgrading measures and policy research (2017BJB011)

2019 Shanghai University "cultural prosperity and social integration" Research Base Project Development Research Center of Shanghai Municipal People's Government: Research on the linkage development strategy of Shanghai manufacturing and Shanghai brand (2019-YJ-H-04)

2019 Government Decision-making Consultation Project - Shanghai Institute of International Finance and Economics: Research on the enlightenment of America, Britain and Germany advanced manufacturing innovation center to Shanghai based on the service-oriented perspective of high-end equipment manufacturing (SIIFE 2019)

\section{References}

[1] A. Kusiak, Service manufacturing: Basic concepts and technologies, Journal of Manufacturing Systems, Vol. 52, 2019, pp.198-204.

[2] C. Parnteiter, Managing and Governing Commodity Chains: the Role of Producer Service Firms in the Scondary Global City of Hamburg, Journal of the Geographical Society of Berlin, Vol.146, No. 1,2014, pp.1-15.

[3] D. Duentes D., On the Limits of Post-Industrial Society: Structural Change and Service Sector Employment in Spain. International Review of Applied Economics, Vol.12,1998, pp. 483-495.

[4] F.F. Yang, A.G.O. Yeh, J.J. Wang, Regional effects of producer services on manufacturing productivity in China, Applied Geography, Vol. 97, 2018, pp.263-274.

[5] F. Yuan, J.L. Gao, L. Wang, Y.Y. Cai, Co-location of manufacturing and producer services in Nanjing, China, Cities, Vol. 63, 2019,pp. 81-91.

[6] H.J. Seo, Y.S. Lee, H. Kim, Does International Specialization in Producer Services Warrant Sustinable Growth?, The Service Industries Journal, Vol. 31, No.8, 2011,pp. 1279-1291.

[7] J.F. Francois, Producer Services, Scale and the Division of Labor, Oxford Economic Papers, Vol. 42,1990, pp. 715-729.

[8] J. Francois, J. Woerz, Producer Services, Manufacturing Linkages and Trade, Journal of Industry Competition and Trade, Vol. 8, No.3, 2008, pp.199-229.

[9] J. Goldhar, D. Berg, Blurring the Boundary: Convergence of Factory and Service Processes, Journal of Manufacturing Technology Management, Vol. 21, No.3, 2010, pp.341-354.

[10] N. Hansen. Do Producer Services Include Regional Economic Development, Journal of Regional Science, Vol.30, No.4, 1990, pp: 65-476.

[11] P. Corina, S.M. Cavia, L.J.L. Martinez, A Petri Net-Based Approach to Incremental Modelling of Flow and Resources in Service-Oriented Manufacturing Systems, International Journal of Production Research, Vol. 50, No.2, 2012, pp.325-343. 
[12] D. Bell, The Coming of Post-Industrial Society. A Venture in Social forecasting, New York Basic Books, 1973.

[13] L.Y. Sun, G. Li, Z.B .Jiang, L. Zheng, Z. He, Advanced Manufacturing Model in the 21st Century--Service-Oriented Manufacturing, China Mechanical Engineering, No. 19,2009, pp.2307 -2312 .

[14] D.P. Zhou, Manufacturing servitization effection to industry transformation, World Economic Research, No.9, 2013, pp.17-22.

[15] L.Yang, Produer Service Import Complexity Affects Manufacturing Added-Value Research,The Journal of Quantitative \& Technical Economics, Vol.33, No.02, 2006, pp.3-20. 